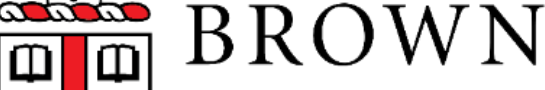 \\ Orlando Bravo Center \\ for Economic Research
}

\section{The Franchise, Policing, and Race: Evidence from Arrests Data and the Voting Rights Act*}

\author{
Bravo Working Paper \# 2020-018
}

Giovanni Facchini $^{\dagger} \quad$ Brian Knight $^{\ddagger} \quad$ Cecilia Testa ${ }^{\S}$

\begin{abstract}
This paper investigates the relationship between the franchise and law enforcement practices using evidence from the Voting Rights Act (VRA) of 1965. We find that, following the VRA, black arrest rates fell in counties that were both covered by the legislation and had a large number of newly enfranchised black voters. We uncover no corresponding patterns for white arrest rates. The reduction in black arrest rates is driven by less serious offenses, for which police might have more enforcement discretion. Importantly, our results are driven by arrests carried out by sheriffs - who are always elected. While there are no corresponding changes for municipal police chiefs in aggregate, we do find similar patterns in covered counties with elected rather than appointed chiefs. We also show that our findings cannot be rationalized by alternative explanations, such as differences in collective bargaining, changes in the underlying propensity to commit crimes, responses to changes in policing practices, and changes in the suppression of civil right protests. Taken together, these results document that voting rights, when combined with elected, rather than appointed, chief law enforcement officers, can lead to improved treatment of minority groups by police.
\end{abstract}

*We would like to thank Pedro Dal Bo, Joan Llull, Hannes Mueller, Abdul Noury, Kevin O'Rourke, Albert Sole-Olle, Etienne Wasmer and seminar audiences at the Universitat Autonoma de Barcelona, Brown University, IEB Universitat de Barcelona, Nottingham University and NYU-Abu Dhabi for very useful comments.

${ }^{\dagger}$ University of Nottingham, CEPR, CES-Ifo and IZA; giovanni.facchini@nottingham.ac.uk.

₹ Brown University and NBER; Brian_Knight@brown.edu.

§University of Nottingham and NICEP; cecilia.testa@nottingham.ac.uk 


\title{
The Franchise, Policing, and Race: Evidence from Arrests Data and the Voting Rights Act*
}

\author{
Giovanni Facchini $^{\dagger} \quad$ Brian Knight $^{\ddagger} \quad$ Cecilia Testa $^{\S}$
}

June 24, 2020

\begin{abstract}
This paper investigates the relationship between the franchise and law enforcement practices using evidence from the Voting Rights Act (VRA) of 1965. We find that, following the VRA, black arrest rates fell in counties that were both covered by the legislation and had a large number of newly enfranchised black voters. We uncover no corresponding patterns for white arrest rates. The reduction in black arrest rates is driven by less serious offenses, for which police might have more enforcement discretion. Importantly, our results are driven by arrests carried out by sheriffs - who are always elected. While there are no corresponding changes for municipal police chiefs in aggregate, we do find similar patterns in covered counties with elected rather than appointed chiefs. We also show that our findings cannot be rationalized by alternative explanations, such as differences in collective bargaining, changes in the underlying propensity to commit crimes, responses to changes in policing practices, and changes in the suppression of civil right protests. Taken together, these results document that voting rights, when combined with elected, rather than appointed, chief law enforcement officers, can lead to improved treatment of minority groups by police.
\end{abstract}

${ }^{*}$ We would like to thank Pedro Dal Bo, Joan Llull, Hannes Mueller, Abdul Noury, Kevin O'Rourke, Albert SoleOlle, Etienne Wasmer and seminar audiences at the Universitat Autonoma de Barcelona, Brown University, IEB Universitat de Barcelona, Nottingham University and NYU-Abu Dhabi for very useful comments.

†University of Nottingham, CEPR, CES-Ifo and IZA; giovanni.facchini@ @ottingham.ac.uk.

${ }_{\ddagger}^{\ddagger}$ Brown University and NBER; Brian_Knight@ brown.edu.

${ }^{\S}$ University of Nottingham and NICEP; cecilia.testa@ nottingham.ac.uk 
"So as opposed to a sheriff being appointed by a mayor or city council and being beholden to that city council, we are beholden to the people. We see our bosses as the citizens that elect us." (Greg Champagne, President of the National Sheriffs' Association) ${ }^{1}$

\section{Introduction}

The treatment of under-represented minority groups by police in the U.S. is a perennially controversial topic. The violent assault of Rodney King by a group of white police officers in Los Angeles during the 1990s led to significant protests, looting, and a national debate over race and policing. The fatal shooting by police, in 2014, of Michael Brown, a black resident of Ferguson, Missouri, also sparked a national debate, with significant protests and a subsequent investigation by the U.S. Department of Justice. The recent death of George Floyd, while restrained by police officers in Minneapolis, has sparked protests and riots across the country, and President Trump has threatened to call in the military to quell the disorders. ${ }^{2}$

While there is substantial and compelling anecdotal evidence of differential treatment of blacks by police, a lopsided pattern of arrests according to race is also reflected in aggregate data. In particular, despite 5.7 whites for every black in the overall population, there are only 2.5 white arrests for every black arrest and only 1.6 whites inmates for every black inmate. Thus, blacks are arrested and incarcerated at much higher rates than whites. ${ }^{3,4}$

An important academic literature has investigated the relationship between race and policing.

\footnotetext{
${ }^{1}$ source: https://www.usnews.com/news/politics/articles/2016-11-04/joe-arpaio-david-clarke-and-why-the-usstill-elect-sheriffs

${ }^{2}$ The incident happened on May 25, 2020.

${ }^{3}$ Inmate data are from the Federal Bureau of Prisons (https://www.bop.gov/about/statistics/statistics_inmate_race.jsp, accessed September 24, 2019), population data are from the Census Bureau (https://www.census.gov/quickfacts/fact/table/US/RHI625218\#RHI625218, accessed September 24, 2019), and arrests data are taken from the FBI UCR statistics (https:/ucr.fbi.gov/crime-in-the-u.s/2017/crime-in-the-u.s.2017/tables/table-43, accessed September 24, 2019).

${ }^{4}$ Anwar, Bayer, and Hjalmarsson (2012) document the presence of a racial bias by white jurors against black defendants, whereas Alesina and La Ferrara (2014) uncover racial bias in capital sentencing.
} 
This body of work has largely focused on the role of the racial composition of the police force, which has historically been dominated by white officers, and examined whether diversifying police forces leads to a shift in arrest patterns according to race. For example, Donohue and Levitt (2001) analyze the relationship between the racial composition of police forces and arrests, finding that an increase in the number of minority police officers is associated with increases in white arrests, but that it does not affect arrest rates for non-whites. McCrary (2007) exploits the timing of federal lawsuits that mandated affirmative action on municipal police departments via hiring quotas. He finds that such litigation does increase the diversity of the police force and subsequently lowers black arrest rates for serious offenses. Bulman (2019) finds that agencies led by black sheriffs, compared to those led by white sheriffs, are associated with a lower black-to-white arrest ratio, and this relationship is driven by less serious offenses. ${ }^{5}$

While significant progress has been made in understanding the effect of the racial composition of both the police force and its leadership on the treatment of black citizens, less is known about the role played by elections and political accountability, a natural topic given that policing is an important public service. This link is important for at least three reasons. First, many chief law enforcement officers (CLEOs) in the United States - all sheriffs in the South and some municipal police chiefs - are directly elected, rather than appointed. Second, CLEOs are in charge of policing practices that have direct effects on the treatment of minorities and might also change departmental culture through their leadership (United States Commission On Civil Rights 2000). ${ }^{6}$ Third, there

\footnotetext{
${ }^{5}$ Another related literature examines whether the differential treatment of blacks by police officers represents statistical discrimination or preference-based discrimination. Knowles, Persico, and Todd (2001) develop an outcomes test, documenting that the outcomes of searches by police during traffic stops does not vary according to race. In the context of their model, this finding is consistent with statistical discrimination. Antonovics and Knight (2009) and Anwar and Fang (2006) also employ information on the race of police officers in these interactions. Antonovics and Knight (2009) find that cross-race interactions, i.e. traffic stops of black drivers by white officers and of white drivers by black officers, are more likely to lead to police searches and argue that this finding is consistent with preferencebased discrimination.

${ }^{6}$ Leadership within organizations can fundamentally shape outcomes (Bertrand and Schoar 2003, Bolton, Brunnermeier, and Veldkamp 2012) and the implications of different methods of selection of chief executives have been studied in a variety of domains (Besley and Coate 2003, Iaryczower, Garrett, and Shum 2013). Surprisingly, very little is known about the implication of different procedures for the selection of US CLEOs. In this paper we make a first step towards addressing this question by focussing on one controversial dimension of enforcement - the treatment of
} 
have been significant changes over time in the franchise for blacks: their right to vote was first granted after the Civil War, then restricted during the Jim Crow era in the U.S. South, and finally reinstated in the South during the 1960s. Even today, there are significant debates over restrictions on voting resulting from, for example, voter ID laws and the disenfranchisement of felons, both of which are believed to disproportionately impact black voters.

To empirically investigate the link between voters, government officials, and the treatment of minority groups by police, we exploit the dramatic change in voting rights brought about by the 1965 Voting Right Act (VRA), which compelled a group of Southern jurisdictions ("covered” under Section 4 of the Act) to remove restrictions on the voting franchise and seek federal authorization for any change of their voting laws (under Section 5 of the same Act). As a result, previously disenfranchised black voters in covered states were newly able to cast their ballot, and thus potentially influence the selection of elected officials. Crucially, given segregated neighborhoods, police treatment of blacks was an important policy area in which white politicians could take steps to improve the lives of black voters, while not necessarily generating backlash from the white electorate (Button 1989).

Anecdotally, a number of CLEOs known for their harsh treatment of blacks were removed from office by voters in the South following the enactment of the VRA in 1965. One particularly emblematic example involves Jim Clark - the sheriff of majority black Dallas County, Alabama who gained notoriety in the "Bloody Sunday" events of 1965, when a group of civil right activists attempting to cross the Pettus Bridge near Selma were brutally beaten by Clark's infamous Sheriff Posse. In the subsequent election held in 1966 - which saw a record number of blacks registering to vote for the first time - he lost office. ${ }^{7}$ Clark was replaced by Wilson Baker, a white moderate overwhelmingly supported by the black electorate. While serving as the public safety director for the

\footnotetext{
minority groups.

${ }^{7}$ In 1965, just before the passage of the VRA, 314 blacks were registered to vote in Dallas county. By 1966, the number of registered blacks increased to 10,267, while the number of registered whites stood at 12,128 (Los Angeles Times, April 17, 1966).
} 
city of Selma at the time of the march, Baker had distanced himself from Clark's actions (Wright 2013, page 189). Importantly, one of Baker's first initiatives as the new sheriff was to dismantle the Posse and “...turn the sheriff's department upside down” (Los Angeles Times, November 10, 1966). The dismissal of Clark was not unique. A similar fate awaited a number of other notorious CLEOs across the U.S. South. ${ }^{8}$ More generally, as the black vote became salient in many electoral races, white sheriffs needed to appeal to this newly enfranchised group. For example, as pointed out by Peirce (1974) "The white sheriff in heavily black Holmes county [Mississippi] won ... by doing an about-face from the old Southern stereotype. "He is terrific", Robert G. Clark, a prominent black politician, acknowledged, "He treats everybody like a man. If he comes to your house with a search warrant, he is polite, and if he has to arrest you, he apologizes for this." (page 189). ${ }^{9}$

In our analysis, we attempt to move beyond anecdotal evidence on changes brought about by the VRA via a systematic causal analysis of the effects of the franchise on treatment of blacks by police. To do so, we examine data on the patterns of arrests by race from the FBI Uniform Crime Reports. If coverage has an effect, areas with larger shares of African Americans should experience a decline in their arrest rates compared to those of whites. However, as the racial composition of arrests in those areas might have changed independently of the federal intervention, the comparison of patterns of arrests by race before and after the VRA is combined in our analysis with the addition of a control group, including jurisdictions of the former Confederacy that were not covered by the VRA. Thus, our baseline analysis compares: 1) arrest patterns for blacks versus whites, 2) before and after the VRA, 3) in covered vs. non-covered areas, and 4) in counties with significant black populations, which are more impacted by the VRA, versus less black counties. Exploiting this

\footnotetext{
${ }^{8}$ Other examples include Clifton Hester (sheriff of Madison County, Louisiana) who fiercely opposed black voters registration drives, stating that “....as long as I am Sheriff, there won't be any niggers registered on the books..." (see Kaplan and Stanzler 1971, page 748), and Lawrence Rayney (sheriff of Neshoba county, Mississippi) who was investigated for alleged involvement in the murder of civil rights activists during the freedom summer campaign in 1964.

${ }^{9}$ In 1967, Robert G. Clark became the first black elected to the Mississippi House of Representative since the Reconstruction era.
} 
variation, our key finding is that arrest rates for blacks fell in counties that were both covered and had a high concentration of black residents. We find no corresponding patterns for white arrest rates. Furthermore, our results are driven by less serious misdemeanor offenses - over which police have more discretion - rather than more serious felonies.

We then turn to explore possible mechanisms. We start by further investigating the electoral channel, by analyzing whether our basic findings differ according to the rules whereby CLEOs are selected. We document that our baseline results are driven by arrests carried out by sheriffs who are always elected - rather than by police chiefs - who are typically appointed. Furthermore, exploiting variation in local statutes and charters prescribing whether police chiefs are appointed or elected, we find that the aggregate pattern we have uncovered is in fact driven by counties where police chiefs are exclusively appointed. In the presence of elected police chiefs, instead, arrests of blacks carried out by municipal police do fall in counties that were both covered and with a high concentration of blacks. All of these results provide prima facie evidence that the VRA, by increasing the accountability of CLEOs to the black electorate, led to changes in police behavior resulting in different racial patterns of arrests.

Although there is abundant evidence that the actions of law enforcement officers in the field are heavily influenced by the practices developed by CLEOs (United States Commission On Civil Rights 2000), it is still possible that our results might be directly driven by the race of CLEOs, other local elected officials, or the police. ${ }^{10}$ To shed light on these alternative mechanisms we start by analyzing the race of CLEOs, documenting the near complete absence of blacks twenty

\footnotetext{
${ }^{10}$ Other elected officials in local jurisdictions, such as commissioners in county governments, and mayors and city council members in municipal governments, might also play a role in developing policing guidelines and practices. For example, in the aftermath of the shooting in Ferguson, some commentators noted that the city council was predominantly white, despite the city being 70 percent black, and that a change in local leadership might be necessary to change policing practices. (see https://www.cnn.com/2015/04/08/us/ferguson-election/index.html, accessed July 10, 2019). Motivated by this argument, the mother of the deceased Michael Brown ran for a seat on the City Council even if her campaign was ultimately unsuccessful. At the same time, the link between these other elected officials and policing practices is unclear, as law enforcement is one of the many functions of local governments in these jurisdictions.
} 
years after the passage of the VRA. This allows us to rule out the identity politics channel for sheriffs or police chiefs. As for other elected officials, we find that covered counties with larger pre-existing shares of African Americans do indeed elect more black county commissioners, but only in the presence of single member districts. Importantly, we do not find any evidence of a differential pattern of arrests in these counties. On the contrary, our results are driven by covered counties that do not experience any increase in the share of black commissioners. Hence, the race of other local office holders does not play an important role in explaining our findings. Last, we investigate whether covered counties experienced a change in the racial composition of the police force that could drive our results. While there was an increase in the South in the number of black police officers, we find no role for the interaction between covered status and the percent of blacks, suggesting that the racial composition of the police force did not play a key role in this period.

We then turn to four alternative explanations for our findings. First, if certain jurisdictions, such as municipalities are more likely to have unionized police forces, CLEO's might be less able to discipline their workforce in case of misconduct. Second, our results could be driven by changes in the blacks' underlying propensity to commit crimes resulting from other changes in the characteristics of the black associated with the VRA: changes in migration, improvements in schooling, or improvements in labor market conditions. Third, crime patterns might respond to changes in policing patterns following the VRA. Fourth, our results could be driven by elevated arrests of blacks at protests during the pre-VRA era. We address each of these in turn and show that our results, especially involving differences in arrest patterns between elected and appointed officials, are not driven by these alternative explanations.

The Civil Rights era brought about a massive realignment of political allegiances in the U.S. South (Kuziemko and Washington 2018). A recent and growing literature has exploited the geographic variation in the VRA provisions to analyze the effect of enfranchisement on the distribution of state funds (Cascio and Washington 2014), on white backlash against the Democratic party (Ang 
2019), on black elected officials in local governments and government spending (Bernini, Facchini, and Testa 2018) and on labor market outcomes (Aneja and Avenancio-Leon 2019). We contribute to this literature by studying the impact of the VRA on the police treatment of blacks. In particular, similarly to Cascio and Washington (2014) - who show how the VRA led to a shift in the allocation of state funds toward black communities by making white politicians more responsive to the interests of black voters - we provide evidence of increased accountability of elected white CLEO's to the black electorate. By doing so, our contribution sheds lights on an issue - the treatment of minorities by the police - lying at the heart of the civil rights movement. In his iconic "I Have a Dream" speech of 1963, Dr. King denounced the unspeakable horrors of police brutality against blacks, while also advocating for their right to vote. ${ }^{11}$ Our findings indicate that the latter proved important in bettering the working of law enforcement, even though much is still left to be done.

The remainder of the paper is organized as follows. Section 2 provides general background on the organization of local police enforcement in the US and on the VRA. Section 3 develops a simple probabilistic voting model to develop our key hypotheses. Section 4 presents the data used in our analysis, whereas section 5 lays out our identification strategy. Section 6 presents our main results, section 7 investigates the alternative mechanisms behind our findings, and section 8 addresses alternative explanations for our results. Section 9 concludes.

\section{Background}

In the US, law enforcement at the local level falls under the authority of sheriff offices - which have county-wide jurisdiction - and municipal police departments - providing police services only within incorporated municipal limits. Despite their county-wide powers, sheriffs mainly focus on policing unincorporated areas, and thus police functions tend to be shared by the two bodies

\footnotetext{
11 "We can never be satisfied as long as the Negro is the victim of the unspeakable horrors of police brutality." (M.L. King 1963).
} 
according to a rural-urban divide. ${ }^{12}$ Besides policing different areas, the two bodies also differ in terms of functions and in the degree of independence from other local governments. In particular, the sheriffs' duties are broader since - besides law enforcement - they are also in charge of county jails and correctional facilities, carry out bailiff duties, and, in some instances, are responsible for the collection of county fees and taxes and the sale of licenses and permits. The office of the sheriff - as an independent entity within county government - also enjoys greater autonomy compared to police departments, whose powers and duties are determined by the administrative branch under which they are authorized and by whom they are in most cases appointed.

Historically modeled after the English sheriff, in colonial America the sheriff was a royal officer appointed by governors. In the post-revolutionary period, the office underwent a major transformation and the election of the sheriff was enshrined in the constitution of many states to make it directly accountable to the local community, rather than to a distant executive. As a result, contemporary sheriffs are popularly elected in nearly 3100 jurisdictions across the US (Falcone and Wells 1995), ${ }^{13}$ and the National Sheriffs' Association strongly supports election as the 'best option' for selecting a county's CLEO, although evidence substantiating the desirability of popular election remains in rather short supply. ${ }^{14}$

As mentioned above, we exploit the dramatic shift in the exercise of the voting franchise of African Americans brought about by the Voting Rights Act of 1965. Ushered through Congress by the Johnson's Administration a few months after the dramatic events in Selma, the momentous federal legislation placed several jurisdictions in the US South under strict federal monitoring of their voting laws and procedures. Under Section 4 of the VRA, jurisdictions that both imposed a

\footnotetext{
${ }^{12}$ In general, police and sheriffs can only make arrests within their respective areas of jurisdiction. The one exception involves hot pursuit, whereby police and sheriffs can arrest criminals in neighboring jurisdictions, but only when the chase began and a crime was committed within their respective jurisdictions.

${ }^{13}$ Sheriffs are appointed in Rhode Island, in two Colorado counties and in Dade County (Florida). There are no sheriffs in Alaska and the office was abolished in the year 2000 in Connecticut. For more details see: https://www.sheriffs.org/sites/default/files/tb/The_Elected_Office_of_Sheriff_-_ An_Executive_Summary.pdf.

${ }^{14}$ See https://www.sheriffs.org/sites/default/files/tb/resolutions/2010-1.pdf.
} 
test or device restricting the right to vote and experienced a turnout below 50 percent in the 1964 Presidential election were placed under strict federal monitoring. As a result, six of the eleven Confederate states - Alabama, Georgia, Louisiana, Mississippi, South Carolina, and Virginia were fully covered and one - North Carolina - was partially covered. ${ }^{15}$ Under Section 5 of the same act, covered jurisdictions had to seek pre-clearance by the US District Court for the District of Columbia or by the Attorney General of any change in legislation affecting voting. Furthermore, the Attorney General could dispatch federal examiners to monitor the activities within these jurisdictions' polling places, and all covered jurisdictions were forced to eliminate literacy test provisions.

As barriers that were a major obstacle to voter registrations were removed, black voters registration and turnout soared (Cascio and Washington 2014; Wright 2013), bringing about an expectation of fundamental changes in policy areas in which the black electorate did not have any voice. The administration of justice was one of such domains. In the US South, where counties were the most important unit of local government, sheriffs - particularly in rural areas - were often the most powerful local officials and the 'principle enforcers of the social and legal convention of the Jim Crow Society...the sheriff sent a signal to the black community: any black citizen entertaining thoughts of challenging the system had only to walk by the local jail to see the hierarchy of race' (Moore 1997, page 53). Under the watch of white sheriffs, black-on-black crime was usually ignored, white-on-black crime was typically not punished, and black-on-white crime was often addressed by extra-legal practices of lynching. In 1961, the report of the US Civil Right Commission on Justice widely acknowledged the issues of widespread police brutality against African Ameri-

\footnotetext{
${ }^{15}$ More precisely, of the 100 North Carolina counties, 39 were covered. Cascio and Washington (2014) focus instead on the removal of literacy test provisions - that were in force in all the six covered states plus North Carolina. In the 1975 re-authorization of the VRA, coverage was extended as to take into account potential discrimination against language minorities. As a result the provision was extended to any jurisdiction where a single language minority group comprised more than 5 percent of the voting age population in 1970 in addition to the turnout threshold and required ballots to be bilingual. Given that our focus is on the effect of the VRA on the arrest rates of African Americans, we adopt the 1965 definition.
} 
cans, advocating for change in leadership as an important way forward to address discrimination in the administration of justice. ${ }^{16}$ The Voting Rights Act, giving voice to previously disenfranchised blacks, provided the tools to bring to power a new type of sheriff. Yet, as white elites resisted change, according to a less benign view, the administration of U.S. criminal justice system in the aftermath of the VRA has become instrumental to the disenfranchisement of African Americans (Alexander 2010). Whether the right to vote led to tangible improvements in the administration of justice in black communities remains therefore an open empirical question that we address, focusing on the analysis of the pattern of arrest by race within constituencies in the Deep South.

\section{Theoretical Model}

This section develops our hypotheses in the context of a simple probabilistic voting model. Let $p$ denote police treatment of blacks, with increases representing harsher treatment. Voters fall into one of two racial groups (Blacks and Whites), e.g. $J=B, W$, where everyone in a given group has the same bliss point over policies, $p^{J}$, with $p^{B}<p^{W}$. The difference in policy preferences might reflect both cultural factors, such as racism on the part of whites, or economic factors, such as an attempt by whites to artificially hold black wages below marginal product via suppression. ${ }^{17}$ Blacks comprise a fraction of the population $\beta$, with whites a fraction $1-\beta$. Two candidates $(c=1$ and $c=2)$ announce credible platforms over policy $\left(p_{1}\right.$ and $\left.p_{2}\right)$. Voters care about both policy and the ideology of candidates. Specifically, voter $i$ in group $J$ prefers candidate 1 if:

$$
V^{J}\left(p_{1}\right)>V^{J}\left(p_{2}\right)+\sigma^{i J}+\delta
$$

\footnotetext{
${ }^{16}$ For more details see United States Commission on Civil Rights (1961)

${ }^{17}$ Acemoglu and Wolitzky (2011) develop a model in which employers use coercion, labeled as "guns", to limit outside options for workers and discuss the role of law enforcement in the U.S. South in coercing black workers.
} 
where $\sigma^{i J} \sim U\left[-\frac{1}{2 \phi}, \frac{1}{2 \phi}\right]$ with density $\phi$ denotes ideological bias toward candidate 2 , and $\delta$ is the average popularity of candidate 2 in the population and is assumed to follow the normal distribution with mean zero and precision $\rho$, with $F$ and $f$ representing the standard normal CDF and density, respectively. ${ }^{18}$ Voters experience a quadratic loss as the platform of candidate $c$ moves away from their bliss point, so that $V^{J}\left(p_{c}\right)=-0.5\left(p_{c}-p^{J}\right)^{2}$. Let $\Delta^{J}=V^{J}\left(p_{1}\right)-V^{J}\left(p_{2}\right)$ represent the payoff difference to group $J$ from the platform of candidate 1 relative to candidate 2 .

In terms of timing, two candidates simultaneously announce their policy platforms: $p_{1}, p_{2}$. They know voter preferences and the distributions of $\sigma^{i J}$ and $\delta$. The value of $\delta$ is realized and elections are held, with the winning candidate implementing his or her platform. Given all of this, the vote share for candidate 1 , conditional on $\delta$, equals:

$$
\pi_{1}=0.5+\beta \phi \Delta^{B}+(1-\beta) \phi \Delta^{W}-\phi \delta
$$

Integrating over $\delta$, candidate 1 's probability of winning equals:

$$
Q_{1}=\operatorname{Pr}\left(\pi_{1} \geq 0.5\right)=F\left[\rho \beta \Delta^{B}+\rho(1-\beta) \Delta^{W}\right]
$$

Candidates care about winning the election but are also citizens and have preferences over policy. In particular, candidates are white, with bliss point $p^{W}$. Candidates place weight $\omega$ on winning and weight $(1-\omega)$ on policy. Thus, the objective for candidate 1 equals:

$$
\omega Q_{1}-(1-\omega)\left[Q_{1} 0.5\left(p_{1}-p^{W}\right)^{2}+\left(1-Q_{1}\right) 0.5\left(p_{2}-p^{W}\right)^{2}\right]
$$

The first term represents the payoff associated with winning the election, and the second term

\footnotetext{
${ }^{18}$ While we label $\sigma^{i J}$ as ideological bias, other interpretations are possible, and this is relevant since elections for CLEOs are sometimes non-partisan. The key role of $\sigma^{i J}$ is that it smooths out candidate vote shares, so that small changes in policies do not lead to discontinuous changes in vote shares.
} 
represents the payoff associated with the policy implemented, which equals $p_{1}$ with probability $Q_{1}$ and $p_{2}$ with probability $1-Q$.

Pre-VRA, only whites can vote, and the probability of candidate 1 winning simplifies to $Q_{1}=$ $F\left[\rho \Delta^{W}\right]$. Given that candidates are white and blacks are disenfranchised, candidates simply cater to the preferences of white voters and set equilibrium policies to those preferred by whites $\left(p^{*}=\right.$ $\left.p^{W}\right) .19$

Post-VRA, both groups can vote, with blacks representing a fraction $\beta$ of the electorate. In this case, white candidates moderate their platforms to account for the demands of black voters. This result is summarized in the following Proposition, with a proof in the Appendix.

Proposition 1 Equilibrium polices can be characterized by a weighted average of black and white bliss points $\left(p^{*}=\alpha p^{B}+(1-\alpha) p^{W}\right)$, with the weight on the black bliss point $(\alpha)$ increasing in the black share of the population $(\beta)$.

Intuitively, equilibrium platforms now account for the preferences of both groups, and the franchise extension effect becomes more pronounced as the black share of the population increases. Thus, the introduction of the VRA improves police treatment of blacks. Moreover, the post-VRA shift in policy towards the preferences of black voters is more significant in places with a larger share of blacks.

We next extend the model to compare elected and appointed CLEOs. There are now two policies: police treatment of blacks $(p)$ and a general policy $(g)$, which can be interpreted as a public good. With elected CLEOs, there are four candidates, two competing over the general policy and two competing over police treatment of blacks. With an appointed CLEO, two candidates compete over the general policy and each commits to appointing a CLEO who will implement an

\footnotetext{
${ }^{19}$ To derive this result, note that the electoral effect of making the policy harsher equals $\frac{\partial Q_{1}}{\partial p_{1}}=-\rho\left(p_{1}-p^{W}\right) f\left[\frac{\Delta^{W}}{\sigma}\right]$. Plugging this into the candidate equilibrium condition and using symmetry $\left(p_{1}=p_{2}, \Delta^{W}=0\right.$ and $\left.Q_{1}=0.5\right)$, equilibrium policies $\left(p^{*}\right)$ can be characterized by $\omega \rho\left(p^{W}-p^{*}\right) f[0]=(1-\omega) 0.5\left(p^{*}-p^{W}\right)$. This can only be satisfied when $p^{*}=p^{W}$.
} 
announced police treatment of blacks. We assume that the full menu of policy options is available when appointing officials. We continue to assume that all officials are white and thus have bliss points $g^{W}$ and $p^{W}$. We also assume that officials can be grouped by parties and that ideology $\sigma^{i J}$ applies to parties as a whole and not specific candidates. Candidates continue to receive popularity shocks $\delta(g)$ and $\delta(p)$, which we assume are independent across candidates. ${ }^{20}$ Voters care about both policies, with separable preferences: $V^{J}\left(g_{1}, p_{1}\right)=-0.5\left(g_{1}-g^{J}\right)^{2}-0.5\left(p_{1}-p^{J}\right)^{2}$. With an elected official as CLEO, candidates compete dimension-by-dimension, given the separability assumption, and the probability of winning for the CLEO from party 1 equals:

$$
Q_{1}=F\left[\rho \beta \Delta^{B}(p)+\rho(1-\beta) \Delta^{W}(p)\right]
$$

where $\Delta^{J}(p)=-0.5\left(p_{1}-p^{J}\right)^{2}-0.5\left(p_{2}-p^{J}\right)^{2}$ represents the difference in utility between candidates for group $J$ in the policing dimension and similarly for $\Delta^{J}(g)$. Given that the probability of winning is identical to that with a single policy dimension, the results are unchanged from above.

With appointed CLEOs, voters must choose a bundle of officials, or equivalently, a party. Importantly, the precision of the combined popularity shock $\delta(g)+\delta(p)$ now equals $\tilde{\rho}=\rho / \sqrt{2}$ and is thus lower than under unbundled elections, meaning that there is more electoral uncertainty under appointed officials than under elected officials. This is due to the fact that voters only have one choice but must consider multiple factors. Given this, candidate 1's probability of winning equals:

$$
Q_{1}=F\left\{\tilde{\rho} \beta\left[\Delta^{B}(p)+\Delta^{B}(g)\right]+\tilde{\rho}(1-\beta)\left[\Delta^{W}(p)+\Delta^{W}(g)\right]\right\}
$$

Since there is now more electoral uncertainty $(\tilde{\rho}<\rho)$, a given shift in policies now translates into smaller changes in the probability of winning. That is, with appointed officials, electoral competition is weakened on a dimension-by-dimension basis, and candidates, with citizen preferences $p^{W}$,

\footnotetext{
${ }^{20}$ This independence assumption can be relaxed so long as preferences are not perfectly correlated.
} 
are less responsive to the preferences of black voters. ${ }^{21,22}$ This leads to the following Proposition, with a proof in the Appendix:

Proposition 2 An increase in the share of black voters $(\beta)$ leads to a larger reduction, or shift towards the preferences of black voters, in $p^{*}$ under elected, rather than appointed, CLEOs.

To summarize, the model makes two key predictions. First, treatment of blacks by police improves following the VRA, and the size of this shift is increasing in the black share of the population. Second, these relationships are more pronounced in jurisdictions with directly elected CLEOs than with appointed CLEOs. We next turn to an empirical investigation of these predictions.

\section{Data}

Our goal is to study how the enfranchisement of African Americans affected racial patterns of law enforcement in the eleven states of the former Confederacy, sharing a similar history of slavery and black disenfranchisement. To do so, we exploit geographic variation in one of the VRA key provisions (coverage) to define a treatment group - including counties that fell under the special provisions of Section 4 - and a control group (those who did not). Figure 1 illustrates the geographic pattern of coverage. As previously discussed, all counties of Alabama, Georgia, Louisiana, Mississippi, South Carolina, and Virginia and 39 counties of North Carolina were covered in 1965, whereas Arkansas, Florida, Tennessee, Texas and 61 counties in North Carolina were not.

To carry out our analysis, we have assembled a dataset on arrests executed by local police offices between 1960-1981. While these data do not include any detailed information on the context

\footnotetext{
${ }^{21}$ Besley and Coate (2003) obtain a similar result in a model with citizen candidates. In particular, with a multidimensional policy space, policy is bundled into one option when officials are appointed, leading them to cater to stakeholders. With elected officials, by contrast, policy becomes unbundled and officials have an incentive to run on pro-voter platforms. Thus, voters have more influence with elected officials relative to appointed ones.

${ }^{22}$ Indeed, as the number of officials appointed by a single elected official grows large, the weight placed on black voters goes to zero and officials do not moderate their platforms towards those preferred by black voters even when the size of the group is large.
} 
around the arrest, such as police use of force, arrests can be considered as a measure of mistreatment of blacks by police. Indeed, as pointed out by Mazumder (2019), arrests and incarceration have been used by white elites in the South as a tool to exert social control over African Americans. The arrests data have been obtained from the Uniform Crime Reports (UCR) - and in particular the "Arrest by County" compilation - which contain information on arrests reported by participating agencies for 29 offense categories by race and age group (adults and juveniles), starting in $1960 .{ }^{23}$ Using these data, we average over the 1960-1965 period to create pre-VRA arrest measures and over the 1975-1980 period to create post-VRA arrest measures.

As we have already discussed, sheriffs have county-wide authority, whereas municipal police has jurisdiction over incorporated areas. In our analysis we use data on arrests at the county level, as this is the administrative unit for which we have information on coverage. County level data on other socio-economic characteristics have been obtained from the Census. ${ }^{24}$

UCR data are based on voluntary filing. As a result, the number of reporting agencies varies over time, and our analysis uses a balanced panel of reporting agencies for 590 counties (out of a universe of 1137), for which we have observations before and after the passage of the VRA. ${ }^{25}$ The geographic coverage of our sample is illustrated in Figure 2, and the number of reporting agencies appears to be scattered throughout the region. Importantly, as shown in Table 1, the key socio-demographic characteristics of the counties included in our analysis are broadly comparable to those of the overall South, even if counties included in our analysis have larger populations and tend to be more urban. ${ }^{26}$ Using these data on arrests, we create race-specific arrest rates per thousand in the population. To measure pre-VRA population, we use the number of blacks and whites in the county in 1960 and, to measure post-VRA population, we use corresponding data on

\footnotetext{
${ }^{23}$ Crime by county data are available from the UCR only starting from 1974.

${ }^{24}$ See the Appendix for the definitions of variables and sources.

${ }^{25}$ See the Appendix for details.

${ }^{26}$ As discussed in Section 5, the analysis carried out in Table A1 and Table A2 shows the absence of selection on observables.
} 
population from the 1980 census

Table 2 presents summary statistics. Before the introduction of the VRA, the overall average arrest rate is 6.29 per thousand for blacks, whereas the corresponding figure for whites is 1.99 . After the passage of the act the number of arrests increases for both subgroups of the population, reaching on average 6.59 per thousand for blacks, and 3.07 for whites. The growth in the arrest rates, defined as the difference in the natural log of arrest rates by county, is on average almost twice as high for whites than for blacks. Municipal police carries out more arrests than sheriff offices, and this is true for both blacks and whites. This is consistent with the fact that sheriffs are policing more rural areas, whereas police departments are in charge of law enforcement in urban areas. In fact, as shown in the top panel of Table 2, counties in the sheriff sample are on average less populated and more rural than those in the police sample. On the other hand, they are broadly comparable on other important characteristics, such as the black population share and the unemployment rate, although the number of families below the poverty line and the share of unskilled is slightly higher in the sheriff sample.

\section{Identification Strategy}

Our main goal is to study the effect of enfranchising black voters on the racial patterns of arrests. If the VRA had an effect, we would expect that areas with a greater share of African Americans should experience an improvement in the treatment of blacks (i.e., a decline in their arrest rates compared to those of whites). However, since areas with a larger concentration of blacks might have seen changes in the racial composition of arrests even in the absence of the specific provisions included in the VRA (coverage), we combine the strategy discussed above with the creation of a control group including the four states of the former Confederacy (Arkansas, Florida, Tennessee and Texas) and 61 counties in North Carolina, with a similar history of slavery and black 
disenfranchisement, which were not covered in 1965. Our baseline strategy is thus based upon a fourfold comparison: 1) arrest patterns for blacks versus whites, 2) before and after the Voting Rights Act, 3) in counties covered by the VRA versus comparable counties in the South, and 4) in counties with significant black populations, which are more affected by the VRA, versus less black counties, which are less affected by it. The first three comparisons are discrete in nature, while the final comparison is based upon a continuous measure, the fraction of blacks in the jurisdiction. We later add two additional comparisons: county versus municipal jurisdictions and more serious versus less serious charges leading to any arrests.

Our identifying assumption is that, in the absence of federal intervention, covered and noncovered jurisdictions would have experienced the same trends in the racial patterns of arrest rates. Although covered and non-covered areas shared a very similar history of racial discrimination and black disenfranchisement, we are concerned that the control group might still exhibit different pretrends in other important outcomes that could be correlated with subsequent changes in the racial patterns of arrests.

To address this concern and to corroborate the validity of our counterfactual, we investigate whether the assumption of parallel trends holds when we consider other important outcomes, such as black political activism, political participation and white racial attitudes between 1950 and 1960 (that is, during the pre-VRA era). The results of this analysis are reported in the Appendix. In particular, Table A.1 documents that covered counties do not display pre-VRA trends in civil rights activism, political participation, and racial attitudes in either our or the U.S. South entire sample. Similarly, Table A.2 documents a similar pattern in the sheriff and police samples. Tables A.3 and A.4 investigate pre-VRA trends in economics and demographic outcomes. We find no changes between covered and non-covered areas in the black population share. Regarding other demographic and economic characteristics, we find statistically significant growth in the population, but only for the sheriff sample (Table A.3) and in the percent rural, but only in the police sample (Table 
A.4). We find instead no evidence of differences in either sample when measuring pre-trends in unemployment, the proportion of unskilled, the share of poor in the population and cotton yield, a proxy for agricultural productivity. Thus, on the whole, we do not find evidence of consistent pre-trends, lending support to our identifying assumption.

\section{Baseline Analysis}

We begin our analysis of the effects of the VRA on the pattern of arrests with Figure 3. In particular, we relate the long-run difference in arrest rates (pre-VRA versus post-VRA) to the share of blacks in the county as of 1960 . Using bin scatter diagrams, we perform this analysis separately for covered and non-covered counties, and also for black and white arrests. As shown in the upper left panel, black arrest rates are growing more quickly in areas with larger shares of African Americans in both covered and non-covered counties. But, importantly, the growth is less pronounced in covered areas, consistent with our hypothesis that enfranchisement leads to better treatment of black residents by police, and especially so in counties with larger shares of African Americans. White arrest rates, by contrast, appear to be independent of the black population in the county, and this is the case for both covered and non-covered areas (see upper right panel). The bottom panel reproduces the same analysis, but using residual growth rates instead, which account for changes in arrests rates that can be explained by observable county characteristics. ${ }^{27}$ As shown, the results are similar to those in the top panels, with rising arrest rates for blacks in counties with more African Americans but, importantly, with slower growth in covered areas. Likewise, there are no differences in the slope of arrest rates for whites with respect to the share of blacks in 1960 for either covered or non-covered counties.

To test for the statistical significance of these long run changes in arrest rates, we next investi-

\footnotetext{
${ }^{27}$ These controls include pre-VRA population (in logs), unemployment rates, poverty rates, percent unskilled, percent rural, cotton suitability, farms with 700 acres or more, pro-black and anti-black protest activity and black police.
} 
gate their patterns in a regression framework. In particular, we estimate the following specification:

$$
\Delta \text { ArrestRates }_{c}=\theta_{1} \text { Black }_{60}+\theta_{2} \text { Cov }_{c}+\theta_{3} \text { Black }_{60} \times \operatorname{Cov}_{c}+\mathbf{X}_{c} \beta+I_{s}+\varepsilon_{r c}
$$

where $\Delta$ ArrestRates $_{c}$ measures the change, from pre-VRA to post-VRA, in the natural log of arrest rates of either black or white individuals in county $c ;$ Black $_{60}$ is the share of blacks in the county as recorded in the 1960 US Census and $\operatorname{Cov}_{c}$ in an indicator taking a value of one if the county was covered in 1965 under Section 4 of the VRA, and zero otherwise. $\mathbf{X}_{c}$ is a set of pre VRA county characteristics - including unemployment rate, share of families below the poverty line, share of unskilled, county population (in logs), share of individuals living in rural areas, measures of proand anti-black activism, cotton suitability, farm size and the number of blacks in the police force in 1959. In some specification we also allow the impact of these controls to vary by treatment status. Finally, $I_{s}$ are state fixed effects - capturing state specific trends in this long difference specification. The main parameter of interest is $\theta_{3}$, which captures the difference in the gradient of the 1960 black population between the treatment and control counties, after controlling for the main effects of the share of blacks in 1960 and coverage status. ${ }^{28}$

Our baseline results are presented in Table 3. Columns 1 and 2 report our most parsimonious specifications, including only the variables of interest and basic economic and demographic controls. In columns 3 and 4, we allow the effects of the additional controls to vary by treatment status. In columns 5-8 we follow the same structure, but we now account also for proxies of black political activism (pro-black activism), white racial attitudes (anti-black activism), historic prevalence of slave labor (cotton suitability), land ownership concentration and presence of blacks in the police force. ${ }^{29}$ As shown, black arrest rates are growing more slowly in covered areas with significant black populations, and these differences are statistically significant when including interactions

\footnotetext{
${ }^{28}$ Note that coverage status does not vary within states, and is thus already incorporated into the state fixed effect, for all cases except North Carolina. Thus, the parameter $\theta_{2}$ is identified only by variation within North Carolina.

${ }^{29}$ Table A5 reports all coefficients for columns (1)-(4).
} 
between coverage and controls (columns 3 and 7). This effect is large in magnitude: an increase in the black share of the population by 10 percentage points, from, say, 20 percent to 30 percent, leads to a 17-23 percent reduction (columns 3 and 7) in the growth of the arrest rate for blacks in covered counties, relative to non-covered counties. ${ }^{30}$ The corresponding analysis using white arrest rates never produces statistically significant differences. ${ }^{31}$ Thus, the regression results also support our main hypothesis, that black arrest rates, relative to white arrest rates, decline in covered counties with significant populations of newly enfranchised black voters, relative to non-covered areas and with smaller black populations.

In Table 4, we introduce an additional comparison: county versus municipal governments. Given that sheriffs are always elected in the South and that municipal police chiefs are often appointed, we expect our baseline results to be driven by county governments. As shown in Table 4, this is indeed the case. Across the four specifications we consider, black versus white arrest rates and county versus municipal governments, the only statistically significant difference in arrest patterns involves the growth in arrests of blacks by sheriffs, who are elected, as documented in column 1. This effect is again large in magnitude: an increase in the black share of the county population by 10 percentage points, from, say, 20 percent to 30 percent, leads to a 31 percent reduction in the growth of the black arrest rate in covered counties, relative to non-covered counties. Differences are small and statistically insignificant for blacks arrested by municipal police (column 3) as well as for whites arrests by both sheriffs (column 2) and municipal police (column 4). The fact that the result is driven by differences in black arrest rates in jurisdictions with elected officials most closely linked to law enforcement (sheriffs) yields credence to our electoral interpretation. In particular, the enfranchisement of blacks led to a change in black arrest rates, and, moreover,

\footnotetext{
${ }^{30}$ Recall that the black share is measured from 0 to 100 and the dependent variable is the log difference, which can be interpreted as the percent growth in the arrest rate.

${ }^{31}$ As for the additional controls - see Table A5 - our results indicate that the arrest rates - for both whites and blacks - grew less in counties with larger initial populations. We also find that counties experiencing more episodes of pro-black activism before the VRA exhibit slower growth in arrest rates for both blacks and whites, as do counties with a larger pre-existing black police force.
} 
this result appears to be driven by elected, rather than appointed officials, with jurisdiction over policing practices.

Our next extension involves the type of offense underlying the arrest. In the U.S., crimes are typically classified into two categories, misdemeanors, which are less serious in nature, and felonies, which are more serious in nature. If our results are driven by changes in policing practices following enfranchisement of black voters, it is natural that such practices should be most strongly reflected in misdemeanor crimes, given that police have more discretion over arrests in these cases. Conversely, we would expect that police have less discretion over whether or not to arrest suspects charged with more serious felony crimes. As shown in Table 5, this does appear to be the case. That is, our baseline results are driven by changes in non-felony arrest rates for blacks, and these results are statistically significant at the 5 percent level. We also uncover a decline in felony arrest rates for blacks, but this result is not statistically significant at conventional levels. ${ }^{32}$ For white arrest rates, we again find no systematic patterns with respect to whether or not the jurisdiction is covered and the size of the black population.

In Table 6, we examine the results separately for type of jurisdiction (county versus municipal government) and type of crime. As shown, our results are driven by non-felony arrests of blacks by county governments (column 2 of the upper panel). This effect is the largest that we have documented. In particular, an increase in the black share of the county population by 10 percentage points, from, say, 20 percent to 30 percent, leads to a 38 percent reduction in the growth of the black arrest rate in covered counties, relative to non-covered counties. While our sample sizes here are small and the results are noisy, we find smaller effects for all coefficients involving municipal governments (columns 1-4 of the lower panel). ${ }^{33}$

\footnotetext{
${ }^{32}$ While the magnitude of the effect is smaller for felonies, these two coefficients are not statistically different from one another, likely because of the small size of our sample

${ }^{33}$ In the Appendix, we also investigate whether our results are driven by arrests of adults versus juveniles. As shown in Tables A6 and A7, the decline in arrest rates in the Sheriff sample is essentially driven by adult arrest rates.
} 


\section{Mechanisms}

Our results thus far document that the enfranchisement of black voters leads to a reduction in black arrest rates, but only when CLEOs are elected, rather than appointed. In this section, we carry out additional exercises to shed light on the mechanisms underlying our findings. We first explore further the role of appointed versus elected CLEOs. We then examine whether our results are driven by an increase in black elected officials. Finally, we study whether changes in the racial composition of police forces could contribute towards our findings.

Starting with the role of different CLEOs selection procedures, we use state-level variation in local statutes and charters allowing for police chiefs in municipal governments to be elected or appointed. ${ }^{34}$ Given our interpretation that electoral systems changed policing practices, we expect that arrests by municipal police in the presence of elected CLEOs should mirror our results regarding arrests by elected sheriffs. Appointed police chiefs, by contrast, are further separated from voters, and we thus expect less responsive policing practices when they are in charge. As shown in the top panel of Table 7, which focuses on municipal governments with elected police chiefs, this is indeed the case: we document reductions in the growth of blacks arrested by municipal police with elected CLEOs, in areas that are covered by VRA and with significant black population shares as of 1960. Although some of these coefficients are less precisely estimated, they are similar in magnitude to those for county governments: an increase in the black share of the county population by 10 percentage points, from, say, 20 percent to 30 percent, leads to an $18-21$ percent reduction in the growth of the black arrest rate in covered areas, relative to non-covered areas. In the bottom panel of Table 7, by contrast, we find no differences between black and white arrest rates when police chiefs are appointed. That is, there is no differential decrease in arrests of blacks by municipal police in covered counties, relative to non-covered counties, with significant

\footnotetext{
${ }^{34}$ The information on rules for the selection of police chiefs is taken from the Census of Government "Elected offices of State and local governments" in 1957 and "Popularly elected officials of State and local governments" for the subsequent years. See Appendix for details.
} 
black populations, relative to less black areas. Taken together, these results indicate that the overall patterns uncovered in Table 3 are driven by areas with elected law enforcement officials and are thus consistent with our hypothesis that enfranchising black voters might have changed policing practices enacted by elected officials and ultimately changed black arrest rates.

Second, we investigate whether our baseline results are due to a change in the race of elected officials or a change in policies holding fixed politicians' race. Towards this end, we use information on the race of elected officials in both county and municipal governments. As explained more in detail in Bernini, Facchini, and Testa (2018), data for the pre-VRA period have been obtained from the Southern Regional Council papers and local newspapers archives, whereas those for subsequent years have been digitized from the National Roster of Black Elected Officials (NRBEO). This information has been combined with Census data on the total number of officials elected to county governments and municipal governments to construct the share of black elected officials in County Commissions, Judicial bodies, CLEOs and Municipal bodies. ${ }^{35}$

Using these data, we find no black sheriffs or elected police chiefs during the pre-VRA era. In 1980, we find only two black sheriffs, both in covered counties, and only three elected police chiefs and marshals (two in covered counties and one in a non-covered county). The small number of sheriffs is likely due to the fact that they tend to be elected county-wide, and very few Southern counties are majority black. Thus, given these very small counts of black elected CLEOs, our documented reduction in black arrest rates following the VRA must be driven by a change in the type or behavior of elected white sheriffs.

${ }^{35}$ More precisely let

$$
\text { ShareBlackElected }_{\text {cot }}=\frac{\text { BlackElected }_{\text {cot }}}{\text { Elected }_{\text {cot }}}
$$

where $c, o$ and $t$ denote county, office and year, respectively. For the numerator, we use the information we have collected from the NRBEO, whereas for the denominator we use data from the Census of Governments for 1967 and 1977. The Census reports the total number of elected officials for county governments (e.g. commission, judiciary and enforcement, and other offices) and municipalities, aggregated at the county level. Unfortunately, there is no separate information available for each county government category. As a result, to compute the share of blacks in each different type of county government we use the total number of elected officials in county governments as the denominator. 
We next investigate the role played by the race of other elected local officials, above and beyond CLEOs. Using again our triple-differences estimation strategy, we regress the long run difference in the share of black elected officials between 1962 and 1981 on the pre-VRA share of blacks and its interaction with the coverage indicator. As shown in Table 8, we do find some evidence of a larger increase in the share of black elected officials at the local level within covered jurisdictions compared to non-covered ones. In particular, we find statistically significant increases in the share of black commissioners (column 1) at the county level, and these effects are large in magnitude. At the same time, we find no effect when we focus on judges. Similarly, we do not uncover an increase in black elected officials in municipal governments.

Given the increase in black county commissioners within covered counties with larger share of blacks, the reduction in black arrests rates we have documented in covered counties could be driven by this greater black representation. To explore whether this is the case, we exploit an additional source of variation, namely the type of rules disciplining local elections, which have been shown to affect minority representation (Trebbi, Aghion, and Alesina 2008). In particular, local officials were elected either by a plurality rule in a unique district covering the entire jurisdiction ("at-large elections"), or in multiple districts ("district system"). The latter system, under which each district elects a single representative, has come to be seen as being in practice more favorable towards minorities (Bernini, Facchini, and Testa 2018). To carry out our analysis, we split the sample distinguishing between elections held by single member districts (SMDs) and other systems. Comparing the results in column 1 in the top and bottom panels of Table 9, the increase in the share of African American commissioners documented above is driven entirely by counties with SMDs elections. By contrast, the decline in black arrests takes place only in non-single member district counties (column 2), despite the fact that such counties do not experience a corresponding increase in black commissioners. In columns 3 and 4, when we additionally allow for the effect of our controls to differ by coverage status, we uncover the same patterns. Taken together, these 
additional findings suggest that our baseline results are driven by white officials (via changes in the behavior of white officials or via newly elected white officials whose views more closely align with those of black voters), rather than by newly elected black officials.

Third, we consider the role of the racial composition of the police force, a factor already investigated by Donohue and Levitt (2001) and McCrary (2007). In particular, it could be that elected officials post-VRA responded by altering the racial composition of the police force to address the demands of black voters, rather than attempting to change the practices of white officers directly. In the first four columns of Table 10 we investigate this question both in the short (columns 1 and 2) and in the long run (columns 3 and 4). The dependent variable in all our regressions is the change in the number of black police officers per capita. The data for the short run analysis have been digitized from Rudwick (1962) and Southern Regional Council (1983) and span the period 1959-1969. The end period data for the long run analysis have been instead obtained from the 1987 Law Enforcement Management and Administrative Statistics (LEMAS) survey (ICPSR 9222), which was administered to all enforcement agencies with at least 100 employees and to a nationally representative sample for smaller entities. As a result, the long run analysis covers a smaller sample. ${ }^{36}$ The short run analysis does not find any relationship between changes in the racial composition of the police force and the pre-existing share of blacks either in the treatment or in the control group. On the other hand, the long run analysis indicates that the number of black police officers (per capita) increased with the share of African Americans in the 1960 population. ${ }^{37}$ This pattern is consistent with the positive time trend uncovered in other studies. ${ }^{38}$ At the same time, we do not find a differential effect between covered and non-covered counties. This evidence

\footnotetext{
${ }^{36}$ We also attempted to access data from EEOC but our FOIA request was denied due to a recent elimination of the data sharing program for researchers.

${ }^{37}$ These coefficients are available upon request.

${ }^{38}$ Donohue and Levitt (2001) who document an increase in the share of black police from 21 percent in 1977 to 38 percent in 1993 (based upon a sample of the 10 largest cities for which they have data). Using a broader sample of 314 cities McCrary (2007) documents an increase in the share of black police from 6 percent in 1970 to 18 percent in 1999.
} 
in consistent with the idea that the change in the racial patterns of arrests is primarily driven by changes in police practices implemented by CLEOs elected after the VRA. Our findings thus corroborate the qualitative evidence reported by the United States Commission On Civil Rights (2000) highlighting that police officers' performance of their duties in the field are "...heavily influenced by the leadership of their department... When incidents of brutality, misconduct or racism occur, the chiefs immediate reaction to these incidents will have a great impact on whether the incident will be repeated in the future" (page 30). ${ }^{39}$

\section{Alternative Explanations}

While our results point to changes in policing practices, there are several alternative explanations for the documented reduction in arrest rates for blacks in covered jurisdictions. First, the ability of CLEOs to change police practices might be constrained by the nature of employment relations in the police force. Since unions may hinder the ability of CLEOs to discipline their workforce following misconduct, and police chiefs tend to face a more unionized force than sheriffs (Zoorob 2020), unionization might drive the observed pattern in arrests rates. Second, it could be that there are changes in the underlying black population following the VRA, leading to changes in the propensity to commit crimes, and hence arrest rates. Third, even in the absence of changes in the black population, the "supply" of crime could vary because of changes in policing practices. Fourth, our results could be driven by elevated levels of black arrests associated with protests during the pre-VRA era. In this section, we attempt to address these alternative explanations in turn.

The first alternative explanation implies that post-VRA changes in unionization may drive the

\footnotetext{
${ }^{39}$ Further support for the role of CLEOs is provided by a survey of randomly selected law enforcement officers carried out by the Police Foundation, summarized in United States Commission On Civil Rights 2000. The main findings was that "approximately 85 percent of the respondents agreed or strongly agreed that a police chief's strong position against the abuse of authority can make a big difference in deterring officers from abusing their authority."
} 
arrest patterns. Note that trade unions have been historically weak in the South and before the passage of the VRA police bargaining rights in this area of the country were severely restricted. None of the former Confederate states had any collective bargaining laws for police in place pre-VRA, and even after 1965 the South continued to lag behind the rest of the country. In fact, as of 1978, only two States - Florida and Louisiana - had introduced state collective bargaining laws for police forces (Ichniowsky 1982). Thus it is unlikely that the effect of elected CLEOs we have uncovered could be driven by patterns of union bargaining power rather than electoral accountability. Nevertheless, in the last two columns of Table 10 we explore this possibility by exploiting information from the 1987 LEMAS survey on agencies covered by collective bargaining agreements to build an indicator of unionization. The latter can be interpreted as a change, given that in the pre-VRA period the number of such agreements is effectively zero. As we can see, patterns of collective bargaining are unrelated to the pre-existing share of blacks, both in the treatment and control groups, and this is true for both the police and the sheriff sample. Hence, while police trade unionism might well play a role elsewhere in the country or in later years, we can rule it out as an important factor in the South during our sample period.

The second alternative explanation involves post-VRA changes in the underlying black population that could lead to changes in propensities to commit crimes unrelated to policing patterns. The underlying black population could change following the VRA for at least three reasons: changes in migration patterns, improvements in education, and improvements in labor market conditions. Regarding migration, as shown in columns (1) and (2) of Table 11, covered counties in the sheriff sample experienced both a significant increase in population and in the share of blacks, whereas we see no differential demographic change in the police sample. This pure population change cannot explain our results, however, since we use time-varying and race-specific measures of population when measuring crime rates. There could be, however, a change in the composition of the African American population, with newly arriving blacks less likely to commit crimes, leading to lower 
arrest rates. To tackle this question, in columns 3-8, we investigate patterns of socio-demographic outcomes that are likely to be related to the propensity to commit crimes (e.g. unemployment, educational attainment and poverty). Our analysis indicates the absence of differential effects between covered and uncovered counties both in the sheriff and in the police samples. This is true when we consider characteristics of the entire population (columns (3)-(5)) and those of blacks alone (columns 6-8), which are reported by the Census for counties with more than 1,000 African Americans.

The third alternative explanation involves changes in the propensity to commit crime by blacks, relative to whites, following the VRA. To the extent that crime responds to enforcement, we might expect an increase in the supply of black crime in response to a reduction in mistreatment of blacks by police. Thus, if anything, changes in the supply of crime should work against our identification strategy, leading us to understate the reduction in black arrests associated with better treatment of blacks by police in covered areas following the VRA.

The fourth alternative explanation involves the suppression of civil rights protests. During the VRA era, there were widespread reports of arrests of African American protesters, perhaps inflating black arrest rates during our pre-period in covered areas and contributing to our documented reduction in black arrests following the VRA. We have attempted to address this issue by controlling for black activism at the county level and interacting this measure of black activism with coverage status. In addition, our results are driven by arrests in the sheriff sample, and, if anything, protests were concentrated in more urban areas, those under the jurisdiction of municipal police chiefs. Thus, arrests of black protesters during the pre-VRA era also cannot explain our key findings. 


\section{Conclusion}

In this paper, we investigate the effect of the enfranchisement of black voters on police practices, as captured by race-specific arrest rates. Following the VRA, which enfranchised black voters, black arrest rates fell in areas both covered by the VRA and with a large number of newly enfranchised black voters. We find no corresponding patterns for white arrest rates. These results are driven by less serious offenses, for which police might naturally have more discretion in arrest decisions, relative to more serious offenses. These results are driven by arrests by county governments, which have elected sheriffs. We do not find corresponding differences on the whole for arrests by municipal governments, but do uncover evidence of our baseline differences in the subset of municipal governments with elected police chiefs, yielding credence to our hypothesized electoral mechanism. We also argue that our results cannot be explained by changes in black's propensity to commit crimes due to either changes in the underlying population or police practices following the VRA, or to a fall in arrests associated with the decline in civil rights protests. Taken together, our results suggest that enfranchisement of minority groups can lead to improved treatment by police but only when CLEOs are elected, rather than appointed.

While historical in nature, these results have significant policy implications today, especially given the ongoing national debates over race and policing and also over voting. On the one hand, although blacks continue to be disproportionately targeted by law enforcement, our results indicate that the election of CLEOs affects accountability and improves the treatment of minority groups by police. On the other, since the franchise matters, should recently enacted changes in the costs of voting, such as voter ID laws, have disproportionate effects on black voters, this might lead to a further worsening of the treatment of minorities by police. Taken together these results emphasize the important link between the administration of justice and the democratic process. 


\section{References}

Acemoglu, D. and A. Wolitzky (2011). The economics of labor coercion. Econometrica 79(2), $555-600$.

Alesina, A. and E. La Ferrara (2014). A test of racial bias in capital sentencing. American Economic Review 104, 3397-3433.

Alexander, M. (2010). The New Jim Crow : Mass Incarceration in the Age of Colorblindness. New Press.

Aneja, A. P. and C. F. Avenancio-Leon (2019). The effect of political power on labor market inequality: Evidence from the 1965 Voting Rights Act. mimeo, UC Berkeley.

Ang, D. (2019). Do 40-year-old facts still matter? Long-run effects of federal oversight under the Voting Rights Act. American Economic Journal: Applied Economics 11, 1-53.

Antonovics, K. and B. G. Knight (2009). A new look at racial profiling: Evidence from the Boston police department. The Review of Economics and Statistics 91, 163-177.

Anwar, S., P. Bayer, and R. Hjalmarsson (2012). The impact of jury race in criminal trials. The Quarterly Journal of Economics 127, 1017-1055.

Anwar, S. and H. Fang (2006). An alternative test of racial prejudice in motor vehicle searches: Theory and evidence. American Economic Review 96, 127-151.

Bernini, A., G. Facchini, and C. Testa (2018). Race, representation and local governments in the US South: the effect of the Voting Rights Act. CEPR Discussion Paper 12774.

Bertrand, M. and A. Schoar (2003). Managing with style: the effect of managers on firm policies. Quarterly Journal of Economics 118, 1169-1208.

Besley, T. and S. Coate (2003). Elected versus appointed regulators: Theory and evidence. Journal of the European Economic Association 1, 1176-1206. 
Bolton, P., M. K. Brunnermeier, and L. Veldkamp (2012). Leadership, Coordination, and Corporate Culture. The Review of Economic Studies 80, 512-537.

Bulman, G. (2019). Law enforcement leaders and the racial composition of arrests. Economic Inquiry 57, 1842-1858.

Button, J. W. (1989). Blacks and Social Change: Impact of the Civil Rights Movement in Southern Communities. Princenton, NJ: Princeton Univreity Press.

Cascio, E. U. and E. Washington (2014). Valuing the vote: The redistribution of voting rights and state funds following the Voting Rights Act of 1965. Quarterly Journal of Economics $129,376-433$.

Donohue, J. J. and S. Levitt (2001). The impact of race on policing and arrests. Journal of Law and Economics 44, 367-394.

Falcone, D. and L. Wells (1995). The county sheriff as a distinctive policing modality. American Journal of Police 14, 123-149.

Hornbeck, R. and S. Naidu (2014). When the levee breaks: Black migration and economic development in the American South. American Economic Review 104, 963-90.

Iaryczower, M., L. Garrett, and M. Shum (2013). To elect or to appoint? Bias, information, and responsiveness of bureaucrats and politicians. Journal of Public Economics 97, 230-244.

Ichniowsky, C. (1982). Arbitration and police bargaining: Prescriptions for the blue flu. Industrial Relations: A Journal of Economy and Society 21, 149-166.

Kaplan, E. and J. Stanzler (1971). Voting rights: A Case Study of Madison Parish, Louisiana. University of Chicago Law Review 38, 726-787.

Knowles, J., N. Persico, and P. Todd (2001). Racial bias in motor vehicle searches: Theory and evidence. Journal of Political Economy 109, 203-229. 
Kuziemko, I. and E. Washington (2018). Why did the democrats lose the South? Bringing new data to an old debate. American Economic Review 108, 2830-67.

Mazumder, S. (2019). A brief moment in the sun: Politics, race, punishment, and the rise of the proto-carceral state. mimeo, Harvard University.

McCrary, J. (2007). The effect of court-ordered hiring quotas on the composition and quality of police. American Economic Review 97, 318-353.

Moore, T. (1997). Race and the county sheriff in the American South. International Social Science Review 72, 50-61.

Peirce, N. R. (1974). The Deep South States of America: People, Politics, and Power in the Seven Deep South States. New York and London: W.W.Norton.

Rudwick, E. M. (1962). The unequal badge; Negro policemen in the South. Atlanta: Southern Regional Council.

Southern Regional Council (1983). Southern Regional Council Papers, 1944-1968, Volume Reel 111. New York: NYT Microfilming Corporation of America.

Trebbi, F., P. Aghion, and A. Alesina (2008). Electoral rules and minority representation in U.S. cities. Quarterly Journal of Economics 123, 325-357.

United States Commission on Civil Rights (1961). United States Commission on Civil Rights report: Justice. Washington, DC.

United States Commission On Civil Rights (2000). Revisiting Who is guarding the guardians? A report on police practices and civil rights in America. Washington, DC: U.S. Commission on Civil Rights.

Wright, G. (2013). Sharing the Prize: The Economics of the Civil Rights Revolution in the American South. Cambridge, MA: Harvard University Press. 
Zoorob, M. (2020). There's (rarely) a new sheriff in town: The incumbency advantage for local law enforcement. mimeo, Harvard University. 
Figure 1: Coverage in 1965

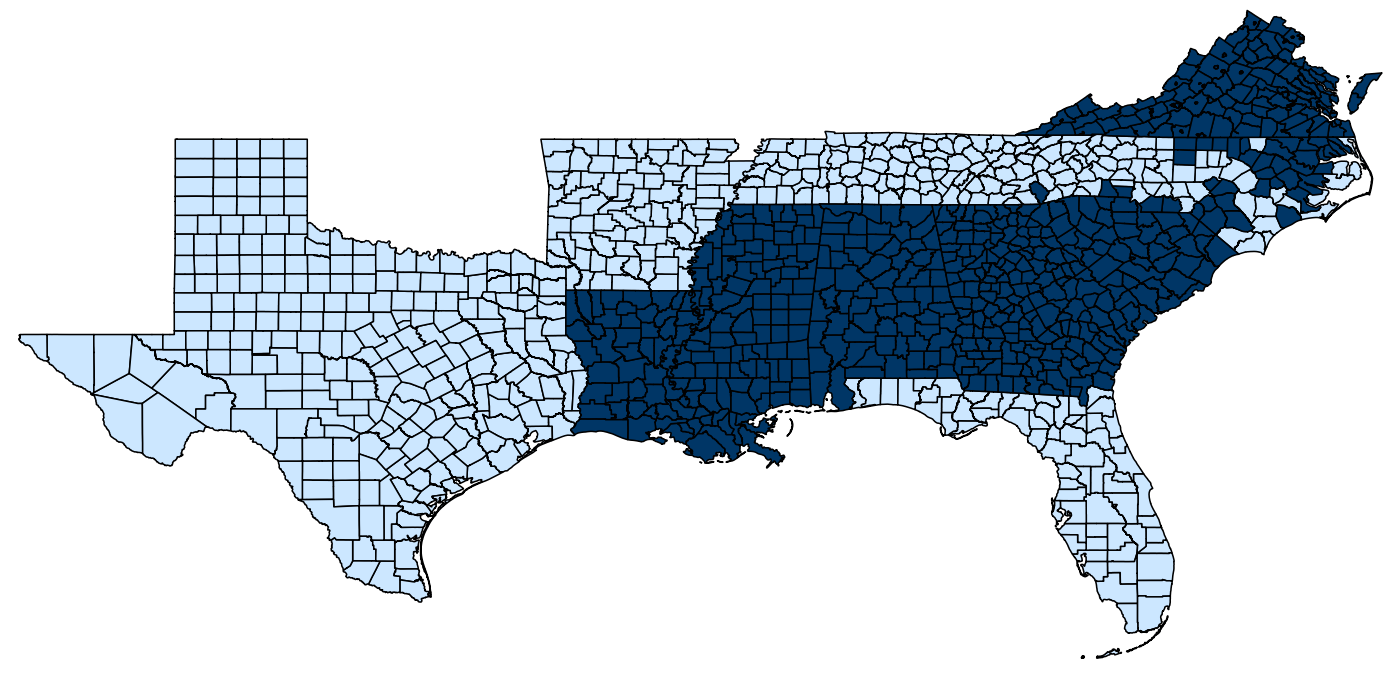

$\square$ Non covered

$\square$ Covered

Figure 2: Arrest rates, sample 1960-1981

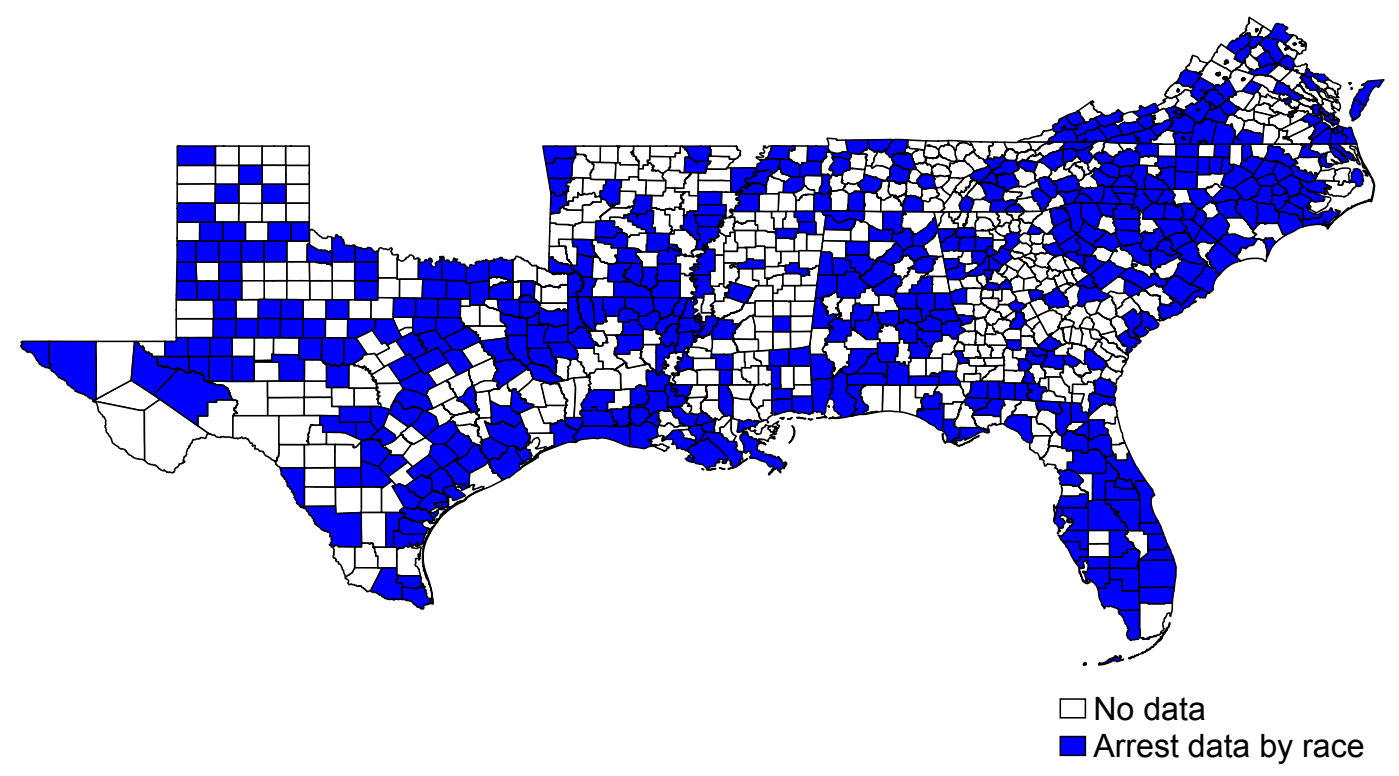


Figure 3: Change in arrest rates (1960-1981), by coverage
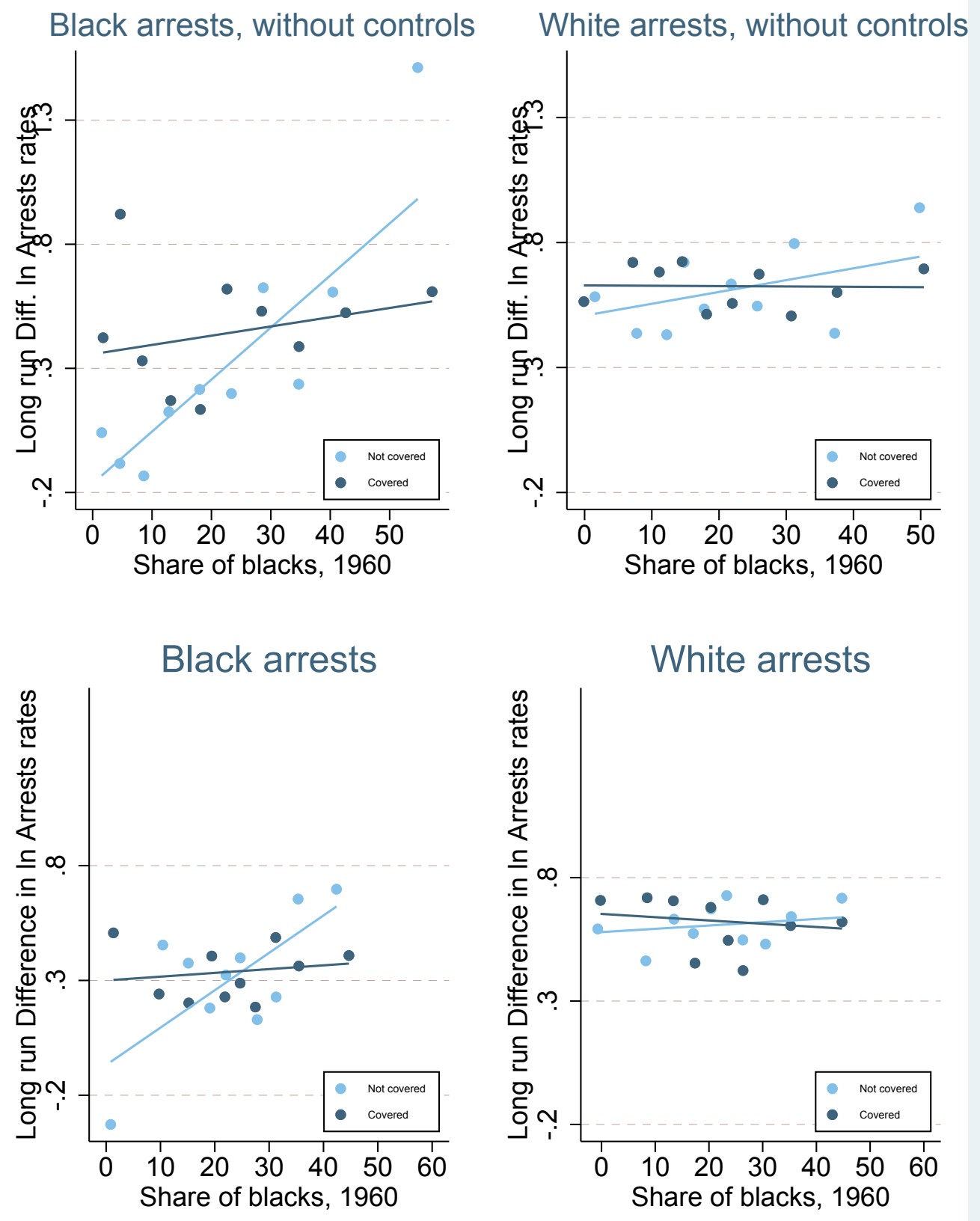

Note: The two figures are binned scatterplot with 10 equally sized bins obtained regressing the long run difference in Ln arrests rates on the share of blacks in 1960. Controls include state trends and the following 1960 county characteristics: population (in logs), unemployment rate, percent family below the poverty line, percent unskilled, percent rural, cotton suitability, farms with 700 acres or more, pro-black protests, anti-black protests, black police in 1959. 
Table 1: Sheriff and Police sample vs. US South sample

\begin{tabular}{lccccc}
\hline & \multicolumn{2}{c}{ Police and Sheriff sample } & & \multicolumn{2}{c}{ US South entire sample } \\
\cline { 2 - 3 } \cline { 5 - 6 } & Mean & St. Dev. & & Mean & St. Dev. \\
\hline County characteristics & & & & \\
& & & & & \\
Percent black, 1960 & 21.50 & 17.73 & & 23.23 & 19.89 \\
Unemployment rate, 1960 & 5.00 & 1.87 & & 4.92 & 2.05 \\
Families below poverty line, 1960 & 41.03 & 14.10 & & 44.96 & 15.65 \\
Percent unskilled, 1960 & 69.98 & 9.10 & & 72.35 & 9.27 \\
County population (1,000), 1960 & 54.40 & 100.52 & & 37.69 & 81.95 \\
Percent rural, 1960 & 17.09 & 13.90 & & 21.04 & 15.21 \\
Pro-black activism, 1960-64 & 1.20 & 5.57 & & 0.83 & 4.65 \\
Anti-black activism, 1960-64 & 0.24 & 1.95 & & 0.18 & 1.51 \\
Cotton suitability & 0.45 & 0.40 & & 0.43 & 0.39 \\
Black police, 1959 & 1.12 & 4.72 & & 0.79 & 6.17 \\
Farms with 700 acres or more & 35.06 & 42.75 & & 32.89 & 42.74 \\
& & & & & 1137 \\
\hline Counties & & 590 & & & \\
\hline
\end{tabular}

Table 2: Summary Statistics

\begin{tabular}{|c|c|c|c|c|c|c|}
\hline & \multicolumn{2}{|c|}{ All } & \multicolumn{2}{|c|}{ Sheriff } & \multicolumn{2}{|c|}{ Police } \\
\hline & Mean & St. Dev. & Mean & St. Dev. & Mean & St. Dev. \\
\hline \multicolumn{7}{|l|}{ County characteristics } \\
\hline Percent black, 1960 & 21.50 & 17.73 & 20.45 & 19.04 & 21.59 & 16.14 \\
\hline Unemployment rate, 1960 & 5.00 & 1.87 & 4.96 & 1.97 & 5.01 & 1.68 \\
\hline Families below poverty line, 1960 & 41.03 & 14.10 & 42.42 & 14.40 & 38.64 & 13.15 \\
\hline Percent unskilled, 1960 & 69.98 & 9.10 & 71.06 & 8.87 & 68.25 & 8.89 \\
\hline County population $(1,000), 1960$ & 54.40 & 100.52 & 48.13 & 91.86 & 69.39 & 116.08 \\
\hline Percent rural, 1960 & 17.09 & 13.90 & 19.53 & 14.59 & 14.15 & 12.58 \\
\hline Pro-black activism, 1960-64 & 1.20 & 5.57 & 0.98 & 5.46 & 1.62 & 6.56 \\
\hline Anti-black activism, 1960-64 & 0.24 & 1.95 & 0.23 & 1.62 & 0.31 & 2.31 \\
\hline Cotton suitability & 0.45 & 0.40 & 0.46 & 0.42 & 0.44 & 0.39 \\
\hline Black police, 1959 & 1.12 & 4.72 & 0.89 & 3.85 & 1.46 & 5.33 \\
\hline Farms with 700 acres or more & 35.06 & 42.75 & 39.91 & 48.45 & 33.42 & 39.69 \\
\hline \multicolumn{7}{|l|}{ Arrest rates } \\
\hline Arrest rate pre-VRA, black & 6.29 & 12.92 & 2.62 & 4.94 & 7.02 & 14.47 \\
\hline Arrest rate post-VRA, black & 6.59 & 10.65 & 3.13 & 6.78 & 5.93 & 11.20 \\
\hline Difference in $\ln$ Arrests rates, black & 0.30 & 1.00 & 0.45 & 1.34 & -0.08 & 0.70 \\
\hline Arrest rate pre-VRA, white & 1.99 & 1.94 & 0.90 & 0.85 & 2.24 & 2.07 \\
\hline Arrest rate post-VRA, white & 3.07 & 2.13 & 1.55 & 1.10 & 2.62 & 2.28 \\
\hline Difference in ln Arrests rates, white & 0.62 & 0.85 & 0.71 & 1.11 & 0.16 & 0.63 \\
\hline Counties & \multicolumn{2}{|c|}{590} & \multicolumn{2}{|c|}{302} & \multicolumn{2}{|c|}{334} \\
\hline
\end{tabular}


Table 3: OLS models. Dependent Variable: Sheriffs and Police, Long run Difference in ln Arrests rates, by race (1960-1981)

\begin{tabular}{|c|c|c|c|c|c|c|c|c|}
\hline & $\begin{array}{c}(1) \\
\text { black }\end{array}$ & $\begin{array}{c}(2) \\
\text { white }\end{array}$ & $\begin{array}{c}(3) \\
\text { black }\end{array}$ & $\begin{array}{c}(4) \\
\text { white }\end{array}$ & $\begin{array}{c}(5) \\
\text { black }\end{array}$ & $\begin{array}{c}(6) \\
\text { white }\end{array}$ & $\begin{array}{c}(7) \\
\text { black }\end{array}$ & $\begin{array}{c}(8) \\
\text { white }\end{array}$ \\
\hline Percent black, 1960 x Coverage & $\begin{array}{c}-0.016 * * \\
(0.006)\end{array}$ & $\begin{array}{l}-0.006 \\
(0.006)\end{array}$ & $\begin{array}{c}-0.017 * * \\
(0.008)\end{array}$ & $\begin{array}{l}-0.003 \\
(0.006)\end{array}$ & $\begin{array}{c}-0.017 * * \\
(0.007)\end{array}$ & $\begin{array}{l}-0.006 \\
(0.006)\end{array}$ & $\begin{array}{c}-0.023 * * \\
(0.009)\end{array}$ & $\begin{array}{l}-0.004 \\
(0.007)\end{array}$ \\
\hline Percent black, 1960 & $\begin{array}{c}0.020 * * * \\
(0.006)\end{array}$ & $\begin{array}{c}0.004 \\
(0.004)\end{array}$ & $\begin{array}{c}0.020 * * * \\
(0.006)\end{array}$ & $\begin{array}{c}0.004 \\
(0.004)\end{array}$ & $\begin{array}{c}0.024 * * * \\
(0.006)\end{array}$ & $\begin{array}{c}0.007 \\
(0.005)\end{array}$ & $\begin{array}{c}0.027 * * * \\
(0.007)\end{array}$ & $\begin{array}{c}0.007 \\
(0.005)\end{array}$ \\
\hline Coverage & $\begin{array}{c}0.472 * * \\
(0.240)\end{array}$ & $\begin{array}{c}0.023 \\
(0.196)\end{array}$ & $\begin{array}{l}-0.172 \\
(0.579)\end{array}$ & $\begin{array}{c}0.168 \\
(0.542)\end{array}$ & $\begin{array}{c}0.588 * * \\
(0.260)\end{array}$ & $\begin{array}{c}0.068 \\
(0.208)\end{array}$ & $\begin{array}{c}0.165 \\
(0.752)\end{array}$ & $\begin{array}{c}1.091 \\
(0.747)\end{array}$ \\
\hline Economic Controls & Yes & Yes & Yes & Yes & Yes & Yes & Yes & Yes \\
\hline Other Controls & No & No & No & No & Yes & Yes & Yes & Yes \\
\hline Coverage X Controls & No & No & Yes & Yes & No & No & Yes & Yes \\
\hline State Trends & Yes & Yes & Yes & Yes & Yes & Yes & Yes & Yes \\
\hline Adj. R-Square & 0.18 & 0.37 & 0.17 & 0.37 & 0.20 & 0.39 & 0.17 & 0.38 \\
\hline $\mathrm{N}$ & 552 & 589 & 552 & 589 & 487 & 524 & 487 & 524 \\
\hline
\end{tabular}

Robust standard errors in parenthesis. $* * *, * *$, and * indicate statistical significance at the $1 \%, 5 \%$ and $10 \%$ levels, respectively. Economic Controls: population, unemployment rate, percent family below the poverty line, percent unskilled, percent rural. Other controls: cotton suitability, farms with 700 acres or more, pro-black protests, anti-black protests, black police. 
Table 4: OLS models. Dependent Variable: Sheriff vs. Police Long run Difference in ln Arrests rates, by race (1960-1981)

\begin{tabular}{|c|c|c|c|c|}
\hline & \multicolumn{2}{|c|}{ Sheriff sample } & \multicolumn{2}{|c|}{ Police sample } \\
\hline & $\begin{array}{c}(1) \\
\text { black }\end{array}$ & $\begin{array}{c}(2) \\
\text { white }\end{array}$ & $\begin{array}{c}(3) \\
\text { black }\end{array}$ & $\begin{array}{c}(4) \\
\text { white }\end{array}$ \\
\hline Percent black, 1960 x Coverage & $\begin{array}{c}-0.031 * * \\
(0.014)\end{array}$ & $\begin{array}{l}-0.011 \\
(0.011)\end{array}$ & $\begin{array}{l}-0.004 \\
(0.008)\end{array}$ & $\begin{array}{c}0.009 \\
(0.006)\end{array}$ \\
\hline Controls & Yes & Yes & Yes & Yes \\
\hline Coverage X Controls & Yes & Yes & Yes & Yes \\
\hline State Trends & Yes & Yes & Yes & Yes \\
\hline Adj. R-Square & 0.14 & 0.31 & 0.14 & 0.22 \\
\hline $\mathrm{N}$ & 247 & 280 & 347 & 361 \\
\hline
\end{tabular}

Robust standard errors in parenthesis. $* * *, * *$, and * indicate statistical significance at the $1 \%, 5 \%$ and $10 \%$ levels, respectively. Controls: percent black, coverage, population, unemployment rate, percent family below the poverty line, percent unskilled, percent rural, cotton suitability, farms with 700 acres or more, pro-black protests, anti-black protests, black police. 
Table 5: OLS models. Dependent Variable: Sheriffs and Police, Long run Difference in In Arrest rates, by race and offense (1960-1981)

\begin{tabular}{lcccc}
\hline & $\begin{array}{c}(1) \\
\text { felony black }\end{array}$ & $\begin{array}{c}(2) \\
\text { non felony black }\end{array}$ & $\begin{array}{c}(3) \\
\text { felony white }\end{array}$ & $\begin{array}{c}(4) \\
\text { non felony white }\end{array}$ \\
\cline { 2 - 5 } Percent black, 1960 x Coverage & -0.014 & $-0.022^{* *}$ & -0.008 & 0.002 \\
& $(0.010)$ & $(0.010)$ & $(0.008)$ & $(0.007)$ \\
Controls & Yes & Yes & Yes & Yes \\
Coverage X Controls & Yes & Yes & Yes & Yes \\
State Trends & Yes & Yes & Yes & Yes \\
\hline Adj. R-Square & 0.56 & 0.15 & 0.69 & 0.29 \\
$\mathrm{~N}$ & 458 & 485 & 512 & 523 \\
\hline
\end{tabular}

Robust standard errors in parenthesis. ***, $* *$, and $*$ indicate statistical significance at the $1 \%, 5 \%$ and $10 \%$ levels, respectively. Controls: percent black, coverage, population, unemployment rate, percent family below the poverty line, percent unskilled, percent rural, cotton suitability, farms with 700 acres or more, pro-black protests, anti-black protests, black police. 
Table 6: OLS models. Dependent Variable: Long run Difference in $\ln$ Arrest rates, by race and offense (1960-1981)

(1)

(2)

(3)

(4)

felony black non felony black felony white non felony white

Sheriff sample

$\begin{array}{lcccc}\text { Percent black, } 1960 \times \text { X Coverage } & -0.024 & -0.038 * * & -0.014 & -0.005 \\ & (0.016) & (0.015) & (0.011) & (0.012)\end{array}$

Controls

Coverage X Controls

State Trends

Adj. R-Square

$\mathrm{N}$

$\begin{array}{cccc}\text { Yes } & \text { Yes } & \text { Yes } & \text { Yes } \\ \text { Yes } & \text { Yes } & \text { Yes } & \text { Yes } \\ \text { Yes } & \text { Yes } & \text { Yes } & \text { Yes } \\ 0.28 & 0.09 & 0.53 & 0.24 \\ 232 & 245 & 278 & 279\end{array}$

Police sample

$\begin{array}{lcccr}\text { Percent black, } 1960 \text { x Coverage } & 0.005 & -0.006 & 0.004 & 0.008 \\ & (0.011) & (0.007) & (0.010) & (0.007)\end{array}$

Controls

Coverage X Controls

Yes

Yes

Yes Yes

State Trends

Yes

Yes

Yes Yes

Adj. R-Square

Yes

Yes

Yes

Yes

$\mathrm{N}$

0.56

0.30

0.65

0.19

323

346

349

361

Robust standard errors in parenthesis. ***, **, and * indicate statistical significance at the $1 \%, 5 \%$ and $10 \%$ levels, respectively. Controls: percent black, coverage, population, unemployment rate, percent family below the poverty line, percent unskilled, percent rural, cotton suitability, farms with 700 acres or more, pro-black protests, anti-black protests, black police. 
Table 7: OLS models. Elected vs Appointed Police Chief. Dependent Variable: Long run Difference in ln Arrests rates, by race (1960-1981)

\begin{tabular}{|c|c|c|c|c|c|c|c|c|}
\hline & $\begin{array}{c}(1) \\
\text { black }\end{array}$ & $\begin{array}{c}(2) \\
\text { white }\end{array}$ & $\begin{array}{c}\text { (3) } \\
\text { black }\end{array}$ & $\begin{array}{c}\text { (4) } \\
\text { white }\end{array}$ & $\begin{array}{c}\text { (5) } \\
\text { black }\end{array}$ & $\begin{array}{c}\text { (6) } \\
\text { white }\end{array}$ & $\begin{array}{c}\text { (7) } \\
\text { black }\end{array}$ & $\begin{array}{c}(8) \\
\text { white }\end{array}$ \\
\hline \multicolumn{9}{|l|}{ Elected Police Chief } \\
\hline Percent black, 1960 x Coverage & $\begin{array}{c}-0.021 * * \\
(0.010)\end{array}$ & $\begin{array}{l}-0.001 \\
(0.010)\end{array}$ & $\begin{array}{l}-0.016 \\
(0.010)\end{array}$ & $\begin{array}{l}-0.006 \\
(0.011)\end{array}$ & $\begin{array}{c}-0.018 * \\
(0.011)\end{array}$ & $\begin{array}{l}-0.004 \\
(0.010)\end{array}$ & $\begin{array}{l}-0.005 \\
(0.010)\end{array}$ & $\begin{array}{l}-0.001 \\
(0.010)\end{array}$ \\
\hline Economic Controls & Yes & Yes & Yes & Yes & Yes & Yes & Yes & Yes \\
\hline Other Controls & No & No & No & No & Yes & Yes & Yes & Yes \\
\hline Coverage X Controls & No & No & Yes & Yes & No & No & Yes & Yes \\
\hline State Trends & Yes & Yes & Yes & Yes & Yes & Yes & Yes & Yes \\
\hline Adj. R-Square & 0.10 & 0.31 & 0.10 & 0.36 & 0.05 & 0.30 & 0.03 & 0.39 \\
\hline $\mathrm{N}$ & 178 & 190 & 178 & 190 & 161 & 173 & 161 & 173 \\
\hline \multicolumn{9}{|l|}{ Appointed Police Chief } \\
\hline Percent black, 1960 x Coverage & $\begin{array}{l}-0.006 \\
(0.007)\end{array}$ & $\begin{array}{c}0.001 \\
(0.008)\end{array}$ & $\begin{array}{l}-0.005 \\
(0.009)\end{array}$ & $\begin{array}{c}0.014 \\
(0.011)\end{array}$ & $\begin{array}{l}-0.003 \\
(0.010)\end{array}$ & $\begin{array}{c}0.004 \\
(0.009)\end{array}$ & $\begin{array}{l}-0.001 \\
(0.011)\end{array}$ & $\begin{array}{c}0.018 \\
(0.013)\end{array}$ \\
\hline Economic Controls & Yes & Yes & Yes & Yes & Yes & Yes & Yes & Yes \\
\hline Other Controls & No & No & No & No & Yes & Yes & Yes & Yes \\
\hline Coverage X Controls & No & No & Yes & Yes & No & No & Yes & Yes \\
\hline State Trends & Yes & Yes & Yes & Yes & Yes & Yes & Yes & Yes \\
\hline Adj. R-Square & 0.15 & 0.08 & 0.14 & 0.10 & 0.17 & 0.09 & 0.16 & 0.09 \\
\hline $\mathrm{N}$ & 221 & 222 & 221 & 222 & 186 & 188 & 186 & 188 \\
\hline
\end{tabular}


Table 8: OLS models. Dependent Variable: Change in black office holding (19601981)

\begin{tabular}{|c|c|c|c|c|}
\hline & \multicolumn{2}{|c|}{ Sheriff sample } & \multicolumn{2}{|c|}{ Police sample } \\
\hline & (1) & (2) & (3) & (4) \\
\hline & Commissioners & Judicial & Municipal council & Judicial \\
\hline \multirow[t]{2}{*}{ Percent black, 1960 x Coverage } & $0.142 * *$ & -0.003 & -0.007 & 0.007 \\
\hline & $(0.070)$ & $(0.005)$ & $(0.079)$ & $(0.012)$ \\
\hline State Trends & Yes & Yes & Yes & Yes \\
\hline Coverage X Controls & Yes & Yes & Yes & Yes \\
\hline Controls & Yes & Yes & Yes & Yes \\
\hline Adj. R-Square & 0.48 & 0.32 & 0.54 & 0.08 \\
\hline $\mathrm{N}$ & 247 & 247 & 347 & 347 \\
\hline
\end{tabular}


Table 9: OLS models. Dependent Variable: Long run Difference in black office holding and black arrests by election rule, sheriff sample (1960-1981)

(1)

Commissioners

Black Arrests

Commissioners

Black Arrests

Single Member District

Percent black, 1960 x Coverage

$\begin{array}{cccc}0.167 * * * & -0.012 & 0.170 * * & -0.019 \\ (0.061) & (0.014) & (0.072) & (0.018)\end{array}$

\begin{tabular}{cccc} 
Yes & Yes & Yes & Yes \\
No & No & Yes & Yes \\
Yes & Yes & Yes & Yes \\
0.54 & 0.14 & 0.55 & 0.10 \\
165 & 165 & 165 & 165 \\
\hline
\end{tabular}

Controls

Coverage X Controls

State Trends

Adj. R-Square

$\mathrm{N}$

Non Single Member district

Percent black, 1960 x Coverage

Controls

$\begin{array}{cccc}\text { Yes } & \text { Yes } & \text { Yes } & \text { Yes } \\ \text { No } & \text { No } & \text { Yes } & \text { Yes } \\ \text { Yes } & \text { Yes } & \text { Yes } & \text { Yes } \\ 0.35 & 0.24 & 0.31 & 0.29 \\ 82 & 82 & 82 & 82\end{array}$

Coverage X Controls

State Trends

Adj. R-Square

82

82

Robust standard errors in parenthesis. $* * *, * *$, and $*$ indicate statistical significance at the $1 \%, 5 \%$ and $10 \%$ levels, respectively. Controls: percent black, coverage, population, unemployment rate, percent family below the poverty line, percent unskilled, percent rural, cotton suitability, farms with 700 acres or more, pro-black protests, anti-black protests, black police. 
Table 10: OLS models. Characteristics of the police force

\begin{tabular}{|c|c|c|c|c|c|c|}
\hline & \multicolumn{4}{|c|}{$\Delta$ number of black police p.c. } & \multirow{2}{*}{\multicolumn{2}{|c|}{$\begin{array}{c}\Delta \text { collective bargaining } \\
1959-1987\end{array}$}} \\
\hline & \multicolumn{2}{|c|}{ 1959-1969 } & \multicolumn{2}{|c|}{ 1959-1987 } & & \\
\hline & (1) & (2) & (3) & (4) & (5) & (6) \\
\hline & Sheriff sample & Police sample & Sheriff sample & Police sample & Sheriff sample & Police sample \\
\hline \multirow[t]{2}{*}{ Percent black, 1960 x Coverage } & 0.001 & -0.000 & 0.003 & -0.003 & -0.004 & -0.001 \\
\hline & $(0.001)$ & $(0.001)$ & $(0.003)$ & $(0.002)$ & $(0.005)$ & $(0.005)$ \\
\hline Controls & Yes & Yes & Yes & Yes & Yes & Yes \\
\hline Coverage X Controls & Yes & Yes & Yes & Yes & Yes & Yes \\
\hline State Trends & Yes & Yes & Yes & Yes & Yes & Yes \\
\hline Adj. R-Square & 0.25 & 0.05 & 0.75 & 0.75 & 0.34 & 0.27 \\
\hline $\mathrm{N}$ & 280 & 361 & 95 & 172 & 95 & 172 \\
\hline
\end{tabular}

Robust standard errors in parenthesis. $* * *, * *$, and * indicate statistical significance at the $1 \%, 5 \%$ and $10 \%$ levels, respectively. Controls: population, unemployment rate, percent family below the poverty line, percent unskilled, percent rural, cotton suitability, farms with 700 acres or more, pro-black protests, anti-black protests. 
Table 11: OLS models. Post-VRA trends, by race (1960-1981)

\begin{tabular}{|c|c|c|c|c|c|c|c|c|}
\hline & \multicolumn{5}{|c|}{ All counties } & \multicolumn{3}{|c|}{ Counties with \# Blacks $\geq 1,000$} \\
\hline & $\begin{array}{c}\text { (1) } \\
\text { Population }\end{array}$ & $\begin{array}{c}(2) \\
\text { Black share }\end{array}$ & $\begin{array}{c}(3) \\
\text { Unemp }\end{array}$ & $\begin{array}{c}\text { (4) } \\
\text { Unskilled }\end{array}$ & $\begin{array}{l}(5) \\
\text { Poor }\end{array}$ & $\begin{array}{c}(6) \\
\text { Black } \\
\text { Unemp }\end{array}$ & $\begin{array}{c}(7) \\
\text { Black } \\
\text { Unskilled }\end{array}$ & $\begin{array}{c}(8) \\
\text { Black } \\
\text { Poor }\end{array}$ \\
\hline \multicolumn{9}{|l|}{ Sheriff Sample } \\
\hline Percent black, 1960 x Coverage & $\begin{array}{c}0.005 * * \\
(0.002)\end{array}$ & $\begin{array}{c}0.105 * * \\
(0.048)\end{array}$ & $\begin{array}{l}-0.002 \\
(0.019)\end{array}$ & $\begin{array}{c}0.022 \\
(0.045)\end{array}$ & $\begin{array}{l}-0.013 \\
(0.042)\end{array}$ & $\begin{array}{l}-0.023 \\
(0.061)\end{array}$ & $\begin{array}{c}0.030 \\
(0.153)\end{array}$ & $\begin{array}{c}0.128 \\
(0.154)\end{array}$ \\
\hline Controls & Yes & Yes & Yes & Yes & Yes & Yes & Yes & Yes \\
\hline Controls x Coverage & Yes & Yes & Yes & Yes & Yes & Yes & Yes & Yes \\
\hline State Trends & Yes & Yes & Yes & Yes & Yes & Yes & Yes & Yes \\
\hline Adj. R-Square & 0.57 & 0.59 & 0.50 & 0.95 & 0.94 & 0.55 & 0.98 & 0.95 \\
\hline $\mathrm{N}$ & 280 & 280 & 280 & 280 & 280 & 172 & 169 & 165 \\
\hline \multicolumn{9}{|l|}{ Police Sample } \\
\hline Percent black, 1960 x Coverage & $\begin{array}{c}0.003 \\
(0.002)\end{array}$ & $\begin{array}{c}0.032 \\
(0.036)\end{array}$ & $\begin{array}{c}0.002 \\
(0.018)\end{array}$ & $\begin{array}{c}0.068 \\
(0.045)\end{array}$ & $\begin{array}{c}0.013 \\
(0.036)\end{array}$ & $\begin{array}{l}-0.030 \\
(0.046)\end{array}$ & $\begin{array}{c}0.033 \\
(0.094)\end{array}$ & $\begin{array}{c}0.137 \\
(0.105)\end{array}$ \\
\hline Controls & Yes & Yes & Yes & Yes & Yes & Yes & Yes & Yes \\
\hline Controls x Coverage & Yes & Yes & Yes & Yes & Yes & Yes & Yes & Yes \\
\hline State Trends & Yes & Yes & Yes & Yes & Yes & Yes & Yes & Yes \\
\hline Adj. R-Square & 0.66 & 0.64 & 0.61 & 0.96 & 0.94 & 0.56 & 0.99 & 0.96 \\
\hline $\mathrm{N}$ & 361 & 361 & 361 & 360 & 361 & 299 & 301 & 294 \\
\hline
\end{tabular}

Robust standard errors in parenthesis. $* * *, * *$, and * indicate statistical significance at the $1 \%, 5 \%$ and $10 \%$ levels, respectively. Robust standard errors in parenthesis. ***,**, and * indicate statistical significance at the $1 \%, 5 \%$ and $10 \%$ levels, respectively. Controls: percent black, coverage, population, unemployment rate, percent family below the poverty line, percent unskilled, percent rural, cotton suitability, farms with 700 acres or more, pro-black protests, anti-black protests, black police. 


\section{Appendix}

\section{Proofs}

Proof of Proposition 1 Taking $p_{2}$ as given, the first-order condition for candidate 1 is given by:

$$
\omega \frac{\partial Q_{1}}{\partial p_{1}}=(1-\omega) \frac{\partial Q_{1}}{\partial p_{1}}\left[0.5\left(p_{1}-p^{W}\right)^{2}-0.5\left(p_{2}-p^{W}\right)^{2}\right]+(1-\omega) Q_{1}\left(p_{1}-p^{W}\right)
$$

Changes in announced platforms by candidate 1 leads to changes in the probability of winning, which has direct effects on candidate payoffs from winning (the left hand size) but also effects on the policies that are implemented and candidate preferences over those policies, as represented by the right-hand side.

Moreover, the effect of making policies harsher on the probability of winning is given by:

$$
\frac{\partial Q_{1}}{\partial p_{1}}=f\left[\rho \beta \Delta^{B}+\rho(1-\beta) \Delta^{W}\right]\left[-\rho \beta\left(p_{1}-p^{B}\right)-\rho(1-\beta)\left(p_{1}-p^{W}\right)\right]
$$

When candidate 1's platform is more harsh than preferred by blacks but less harsh than preferred by whites $\left(p^{B}<p_{1}<p^{W}\right)$, making policies more harsh leads to more support from white voters but less support from black voters. Putting this back into the candidate equilibrium condition above, using symmetry, and re-arranging, equilibrium polices can be characterized by a weighted average of black and white bliss points:

$$
p^{*}=\alpha p^{B}+(1-\alpha) p^{W}
$$


where the weight on policy preferences of black voters equals:

$$
\alpha=\frac{\omega f(0) \rho \beta}{\omega f(0) \rho \beta+\omega f(0) \rho(1-\beta)+(1-\omega)}
$$

Finally, the weight on the policy preferences of black voters is increasing in the black share of the population $(\beta)$.

Proof of Proposition 2 With an appointed CLEO, the pre-VRA equilibrium is unchanged $\left(p^{*}=\right.$ $p^{W}$ ) but the post-VRA equilibrium in police treatment of blacks is given by:

$$
p^{*}=\tilde{\alpha} p^{B}+(1-\tilde{\alpha}) p^{W}
$$

where the weight on black preferences now equals:

$$
\tilde{\alpha}=\frac{\omega f(0) \tilde{\rho} \beta}{\omega f(0) \tilde{\rho} \beta+\omega f(0) \tilde{\rho}(1-\beta)+(1-\omega)}
$$

A marginal increase in the share of black voters shifts equilibrium policy towards those preferred by blacks in proportion to the weight placed on black voters by policy makers. That is, $\partial \alpha / \partial \beta=\alpha / \beta$ and $\partial \tilde{\alpha} / \partial \beta=\tilde{\alpha} / \beta$. Moreover, one can show that $\alpha>\tilde{\alpha}$ due to the fact that $\rho>\tilde{\rho}$ and so long as candidates place some weight on both policy and winning $(0<\omega<1)$. Thus, a marginal increase in the share of black voters leads to a bigger shift in police treatment of blacks under elected officials than under appointed CLEOs. 
Table A1: OLS models. Pre-VRA trends in civil right activism, political participation and racial attitudes sample

\begin{tabular}{|c|c|c|c|c|c|c|}
\hline & \multicolumn{3}{|c|}{ Police and Sheriff sample } & \multicolumn{3}{|c|}{ US South entire sample } \\
\hline & $\begin{array}{c}\text { NACCP } \\
\text { (1) }\end{array}$ & $\begin{array}{c}\text { Turnout } \\
\text { (2) }\end{array}$ & $\begin{array}{c}\text { KKK } \\
(3)\end{array}$ & $\begin{array}{c}\text { NACCP } \\
(4)\end{array}$ & $\begin{array}{c}\text { Turnout } \\
\text { (5) }\end{array}$ & $\begin{array}{c}\text { KKK } \\
(6)\end{array}$ \\
\hline Percent black, 1960 x Coverage & $\begin{array}{l}0.0115 \\
(0.012)\end{array}$ & $\begin{array}{c}-0.0002 \\
(0.001)\end{array}$ & $\begin{array}{c}-0.0472 \\
(0.044)\end{array}$ & $\begin{array}{l}0.0016 \\
(0.004)\end{array}$ & $\begin{array}{l}0.0001 \\
(0.001)\end{array}$ & $\begin{array}{c}-0.0594 \\
(0.051)\end{array}$ \\
\hline
\end{tabular}

\begin{tabular}{lcccccc} 
Controls & Yes & Yes & Yes & Yes & Yes & Yes \\
Controls x Coverage & Yes & Yes & Yes & Yes & Yes & Yes \\
State Trends & Yes & Yes & Yes & Yes & Yes & Yes \\
\hline Adj. R-Square & -0.02 & 0.93 & 0.02 & -0.01 & 0.92 & 0.02 \\
$\mathrm{~N}$ & 508 & 515 & 508 & 978 & 997 & 978 \\
\hline
\end{tabular}

Robust standard errors in parenthesis. $* * *, * *$, and $*$ indicate statistical significance at the $1 \%, 5 \%$ and $10 \%$ levels, respectively. Controls: percent black, coverage, population, unemployment rate, percent family below the poverty line, percent unskilled, percent rural, cotton suitability, farms with 700 acres or more, pro-black protests, anti-black protests, black police. 
Table A2: OLS models. Pre-VRA trends in civil right activism, political participation and racial attitudes sample

\begin{tabular}{|c|c|c|c|c|c|c|}
\hline & \multicolumn{3}{|c|}{ Sheriff sample } & \multicolumn{3}{|c|}{ Police sample } \\
\hline & $\begin{array}{c}\text { NACCP } \\
\text { (1) }\end{array}$ & $\begin{array}{c}\text { Turnout } \\
\text { (2) }\end{array}$ & $\begin{array}{c}\text { KKK } \\
(3)\end{array}$ & $\begin{array}{c}\text { NACCP } \\
(4)\end{array}$ & $\begin{array}{c}\text { Turnout } \\
\text { (5) }\end{array}$ & $\begin{array}{c}\text { KKK } \\
(6)\end{array}$ \\
\hline Percent black, 1960 x Coverage & $\begin{array}{l}0.0068 \\
(0.013)\end{array}$ & $\begin{array}{l}0.0030 \\
(0.002)\end{array}$ & $\begin{array}{c}-0.1818 \\
(0.152)\end{array}$ & $\begin{array}{l}0.0015 \\
(0.001)\end{array}$ & $\begin{array}{c}-0.0002 \\
(0.002)\end{array}$ & $\begin{array}{c}-0.0057 * \\
(0.003)\end{array}$ \\
\hline
\end{tabular}

\begin{tabular}{lcccccc} 
Controls & Yes & Yes & Yes & Yes & Yes & Yes \\
Controls x Coverage & Yes & Yes & Yes & Yes & Yes & Yes \\
State Trends & Yes & Yes & Yes & Yes & Yes & Yes \\
\hline Adj. R-Square & -0.07 & 0.93 & 0.12 & 0.15 & 0.94 & 0.10 \\
$\mathrm{~N}$ & 267 & 277 & 267 & 353 & 355 & 353 \\
\hline
\end{tabular}

Robust standard errors in parenthesis. $* * *, * *$, and $*$ indicate statistical significance at the $1 \%, 5 \%$ and $10 \%$ levels, respectively. Controls: percent black, coverage, population, unemployment rate, percent family below the poverty line, percent unskilled, percent rural, cotton suitability, farms with 700 acres or more, pro-black protests, anti-black protests, black police. 
Table A3: OLS models. Pre-VRA trends in economic and demographic variables (1960-1950 difference), Sheriff Sample sample

\begin{tabular}{lccccccc}
\hline & Black Share & Population & Unemp & Rural & Unskilled & Poor & \multicolumn{2}{c}{ Cotton Yield } \\
& $(1)$ & $(2)$ & $(3)$ & $(4)$ & $(5)$ & $(6)$ & $(7)$ \\
\cline { 2 - 8 } Percent black, 1960 x Coverage & 0.0158 & $0.0020^{* *}$ & -0.0089 & 0.1047 & -0.0195 & -0.0350 & -0.0030 \\
& $(0.019)$ & $(0.001)$ & $(0.014)$ & $(0.070)$ & $(0.023)$ & $(0.051)$ & $(0.003)$ \\
Controls & & & & & & & \\
Controls x Coverage & Yes & Yes & Yes & Yes & Yes & Yes & Yes \\
State Trends & Yes & Yes & Yes & Yes & Yes & Yes & Yes \\
\hline Adj. R-Square & Yes & Yes & Yes & Yes & Yes & Yes & Yes \\
$\mathrm{N}$ & 0.34 & 0.60 & 0.69 & 0.88 & 0.87 & 0.81 & 0.33 \\
\hline
\end{tabular}

Robust standard errors in parenthesis. $* * *, * *$, and $*$ indicate statistical significance at the $1 \%, 5 \%$ and $10 \%$ levels, respectively. Controls: percent black, coverage, population, unemployment rate, percent family below the poverty line, percent unskilled, percent rural, cotton suitability, farms with 700 acres or more, pro-black protests, anti-black protests, black police. 
Table A4: OLS models. Pre-VRA trends in economic and demographic variables (1960-1950 difference), Police Sample sample

\begin{tabular}{lccccccc}
\hline & Black Share & Population & Unemp & Rural & Unskilled & Poor & Cotton Yield \\
& $(1)$ & $(2)$ & $(3)$ & $(4)$ & $(5)$ & $(6)$ & $(7)$ \\
\cline { 2 - 8 } Percent black, 1960 x Coverage & 0.0348 & 0.0013 & -0.0163 & $0.1697 * *$ & 0.0338 & 0.0468 & -0.0030 \\
& $(0.037)$ & $(0.001)$ & $(0.017)$ & $(0.067)$ & $(0.028)$ & $(0.056)$ & $(0.003)$ \\
Controls & & & & & & & \\
Controls x Coverage & Yes & Yes & Yes & Yes & Yes & Yes & Yes \\
State Trends & Yes & Yes & Yes & Yes & Yes & Yes & Yes \\
\hline Adj. R-Square & 0.37 & 0.70 & 0.61 & 0.89 & 0.90 & 0.83 & 0.39 \\
$\mathrm{~N}$ & 361 & 361 & 361 & 361 & 361 & 361 & 361 \\
\hline
\end{tabular}

Robust standard errors in parenthesis. ***, **, and * indicate statistical significance at the $1 \%, 5 \%$ and $10 \%$ levels, respectively. Controls: percent black, coverage, population, unemployment rate, percent family below the poverty line, percent unskilled, percent rural, cotton suitability, farms with 700 acres or more, pro-black protests, anti-black protests, black police. 
Table A5: OLS models. Dependent Variable: Sheriffs and Police, Long run Difference in ln Arrests rates, by race (1960-1981)

\begin{tabular}{|c|c|c|c|c|}
\hline & $\begin{array}{c}(1) \\
\text { black }\end{array}$ & $\begin{array}{c}(2) \\
\text { white }\end{array}$ & $\begin{array}{c}(3) \\
\text { black }\end{array}$ & $\begin{array}{c}(4) \\
\text { white }\end{array}$ \\
\hline Percent black, 1960 x Coverage & $\begin{array}{c}-0.016 * * \\
(0.006)\end{array}$ & $\begin{array}{l}-0.006 \\
(0.006)\end{array}$ & $\begin{array}{c}-0.017 * * \\
(0.007)\end{array}$ & $\begin{array}{l}-0.006 \\
(0.006)\end{array}$ \\
\hline Percent black, 1960 & $\begin{array}{c}0.020 * * * \\
(0.006)\end{array}$ & $\begin{array}{c}0.004 \\
(0.004)\end{array}$ & $\begin{array}{c}0.024 * * * \\
(0.006)\end{array}$ & $\begin{array}{c}0.007 \\
(0.005)\end{array}$ \\
\hline Coverage & $\begin{array}{c}0.472 * * \\
(0.240)\end{array}$ & $\begin{array}{c}0.023 \\
(0.196)\end{array}$ & $\begin{array}{c}0.588 * * \\
(0.260)\end{array}$ & $\begin{array}{c}0.068 \\
(0.208)\end{array}$ \\
\hline Unemployment rate, 1960 & $\begin{array}{l}-0.020 \\
(0.034)\end{array}$ & $\begin{array}{l}-0.015 \\
(0.024)\end{array}$ & $\begin{array}{l}-0.036 \\
(0.036)\end{array}$ & $\begin{array}{l}-0.018 \\
(0.025)\end{array}$ \\
\hline Percent family bottom 20, 1960 & $\begin{array}{c}0.003 \\
(0.008)\end{array}$ & $\begin{array}{c}0.005 \\
(0.005)\end{array}$ & $\begin{array}{c}0.001 \\
(0.008)\end{array}$ & $\begin{array}{l}-0.000 \\
(0.006)\end{array}$ \\
\hline Percent unskilled, 1960 & $\begin{array}{l}-0.002 \\
(0.005)\end{array}$ & $\begin{array}{c}0.008 * * \\
(0.004)\end{array}$ & $\begin{array}{l}-0.001 \\
(0.005)\end{array}$ & $\begin{array}{c}0.010 * * \\
(0.004)\end{array}$ \\
\hline County population $(1,000), 1960$ & $\begin{array}{c}-0.001 * * * \\
(0.000)\end{array}$ & $\begin{array}{c}-0.001 * * * \\
(0.000)\end{array}$ & $\begin{array}{l}-0.001 \\
(0.000)\end{array}$ & $\begin{array}{c}-0.001 * * \\
(0.000)\end{array}$ \\
\hline Percent rural, 1960 & $\begin{array}{c}0.007 \\
(0.006)\end{array}$ & $\begin{array}{l}-0.001 \\
(0.004)\end{array}$ & $\begin{array}{c}0.003 \\
(0.006)\end{array}$ & $\begin{array}{l}-0.001 \\
(0.005)\end{array}$ \\
\hline Pro-black activism, 1960-64 & & & $\begin{array}{c}-0.009 * * \\
(0.004)\end{array}$ & $\begin{array}{c}-0.009 * * \\
(0.004)\end{array}$ \\
\hline Anti-black activism, 1960-64 & & & $\begin{array}{c}0.013 \\
(0.013)\end{array}$ & $\begin{array}{c}0.017 \\
(0.015)\end{array}$ \\
\hline Cotton suitability & & & $\begin{array}{c}-0.343 * \\
(0.176)\end{array}$ & $\begin{array}{l}-0.222 \\
(0.165)\end{array}$ \\
\hline Farms with 700 acres or more & & & $\begin{array}{c}0.001 \\
(0.002)\end{array}$ & $\begin{array}{l}-0.000 \\
(0.001)\end{array}$ \\
\hline Black police, 1959 & & & $\begin{array}{c}-0.012 * * \\
(0.005)\end{array}$ & $\begin{array}{l}-0.005 \\
(0.010)\end{array}$ \\
\hline State Trends & Yes & Yes & Yes & Yes \\
\hline Coverage X Controls & No & No & No & No \\
\hline Adj. R-Square & 0.18 & 0.37 & 0.20 & 0.39 \\
\hline $\mathrm{N}$ & 552 & 589 & 487 & 524 \\
\hline
\end{tabular}

Robust standard errors in parenthesis. $* * *, * *$, and $*$ indicate statistical significance at the $1 \%, 5 \%$ and $10 \%$ levels, respectively. 
Table A6: OLS models. Dependent Variable: Sheriffs Long run Difference in ln Arrest rates, by race and age (1960-1981)

\begin{tabular}{lcccc}
\hline & $\begin{array}{c}(1) \\
\text { adult black }\end{array}$ & $\begin{array}{c}(2) \\
\text { juvenile black }\end{array}$ & $\begin{array}{c}(3) \\
\text { adult white }\end{array}$ & $\begin{array}{c}(4) \\
\text { juvenile white }\end{array}$ \\
\cline { 2 - 5 } Percent black, 1960 x Coverage & $-0.030^{* *}$ & -0.012 & -0.011 & 0.016 \\
& $(0.014)$ & $(0.062)$ & $(0.011)$ & $(0.020)$ \\
Controls & Yes & Yes & Yes & Yes \\
Coverage X Controls & Yes & Yes & Yes & Yes \\
State Trends & Yes & Yes & Yes & Yes \\
\hline Adj. R-Square & 0.12 & 0.43 & 0.27 & 0.41 \\
$\mathrm{~N}$ & 247 & 74 & 280 & 119 \\
\hline
\end{tabular}

Robust standard errors in parenthesis. $* * *, * *$, and * indicate statistical significance at the $1 \%$, $5 \%$ and $10 \%$ levels, respectively. Controls: percent black, coverage, population, unemployment rate, percent family below the poverty line, percent unskilled, percent rural, cotton suitability, farms with 700 acres or more, pro-black protests, anti-black protests, black police.

Table A7: OLS models. Dependent Variable: Police Long run Difference in ln Arrest rates, by race and age (1960-1981)

\begin{tabular}{lcccc}
\hline & $\begin{array}{c}(1) \\
\text { adult black }\end{array}$ & $\begin{array}{c}(2) \\
\text { juvenile black }\end{array}$ & $\begin{array}{c}(3) \\
\text { adult white }\end{array}$ & $\begin{array}{c}(4) \\
\text { juvenile white }\end{array}$ \\
\cline { 2 - 5 } Percent black, 1960 x Coverage & -0.004 & -0.011 & 0.009 & 0.002 \\
& $(0.007)$ & $(0.018)$ & $(0.006)$ & $(0.016)$ \\
Controls & Yes & Yes & Yes & Yes \\
Coverage X Controls & Yes & Yes & Yes & Yes \\
State Trends & Yes & Yes & Yes & Yes \\
\hline Adj. R-Square & 0.20 & 0.70 & 0.17 & 0.74 \\
N & 347 & 214 & 361 & 242 \\
\hline
\end{tabular}

Robust standard errors in parenthesis. ${ }^{* * *}, * *$, and $*$ indicate statistical significance at the $1 \%$, $5 \%$ and $10 \%$ levels, respectively. Controls: percent black, coverage, population, unemployment rate, percent family below the poverty line, percent unskilled, percent rural, cotton suitability, farms with 700 acres or more, pro-black protests, anti-black protests, black police. 


\section{Variable definitions and sources}

\section{Arrests data.}

Arrests executed by local police offices between 1960-1981 have been obtained from the Uniform Crime Reports (UCR) reporting information on arrests by race and local enforcement agency provided by voluntary filing. Since the number of reporting agencies varies over time, we have retained only agencies for which we have information before and after the VRA passage to build a panel of municipal police and sheriff offices that we have subsequently mapped to counties, obtaining a balanced panel of 484 counties (out of a universe of 1137) for the pre-VRA (1960-1965) and post-VRA (1975-1980) periods. These data have been combined with Census data on population by county to construct the average county arrest rates pre-VRA (1960-1965) and post-VRA (1975-1980) described below.

Arrest rate pre-VRA, black: Black arrests per thousands (1960-1965).

Arrest rate pre-VRA, white: White arrests per thousands (1960-1965).

Arrest rate post-VRA, black: Black arrests per thousands (1975-1980).

Arrest rate post-VRA, white: White arrests per thousands (1975-1980).

Difference in Ln Arrest rate, black: Difference between the natural log of black arrest rates post-VRA and pre-VRA.

Difference in Ln Arrest rate, white: Difference between the natural log of white arrest rates post-VRA and pre-VRA.

\section{Coverage.}

Dummy variable equal to one for the counties that were covered under Section 5 of the VRA in 1965 and zero otherwise. All counties of six states (Alabama, Georgia, Louisiana, Mississippi, South Carolina, and Virginia) were covered, whereas, of the 100 North Carolina counties, 39 were 
covered, i.e. Anson, Beaufort, Bertie, Bladen, Camden, Caswell, Chowan, Cleveland, Craven, Cumberland, Edgecombe, Franklin, Gaston, Gates, Granville, Greene, Guilford, Halifax, Harnett, Hertford, Hoke, Jackson, Lee, Martin, Nash, Northampton, Onslow, Pasquotank, Perquimans, Person, Pitt, Robeson, Rockingham, Scotland, Union, Vance, Washington, Wayne, Wilson (source: https://www.justice.gov/crt). All counties of Arkansas, Florida, Tennessee, and Texas were instead not covered.

\section{County characteristics.}

Percent black, 1960: percent black in the 1960 county population is from the County and City Data Book Consolidated File, County Data 1947-1977 (U.S. Department of Commerce 1978).

Population, 1960: the county population is from the County and City Data Book Consolidated File, County Data 1947-1977 (U.S. Department of Commerce 1978).

Unemployment rate, 1960: county unemployment rate is from the County and City Data Book Consolidated File, County Data 1947-1977 (U.S. Department of Commerce 1978).

Percent poor, 1960: percentage of families with income less than 3,000 USD in 1960 is from the County and City Data Book Consolidated File, County Data 1947-1977 (U.S. Department of Commerce 1978).

Percent unskilled, 1960: county percentage of 25 years old or more without a high school diploma in 1960 is from the County and City Data Book Consolidated File, County Data 19471977 (U.S. Department of Commerce 1978).

Percent rural, 1960: county percentage of population living in rural farms in 1960 is from the County and City Data Book Consolidated File, County Data 1947-1977 (U.S. Department of Commerce 1978).

Pro-black activism, 1960-64: counts of pro-black events occurred between 1960 and 1964 as reported by the Dynamics of Collective Action Dataset by states and cities, matched to counties by 
the authors. Source: web.stanford.edu/group/collectiveaction/cgi-bin/drupal.

Anti-black activism, 1960-64: counts of anti-black events occurred between 1960 and 1964 as reported by the Dynamics of Collective Action Dataset by states and cities, matched to counties by the authors. Source: web.stanford.edu/group/collectiveaction/cgi-bin/drupal.

NAACP: change in the standardized (by black population) count of local branches of the National Association for the Advancement of Colored People (NAACP), by county, between 1940 and 1964. The information on the location of local branches of the NAACP has been obtained from the University of Washington's project 'Mapping American Social Movements Through the 20th Century', which reports the municipality of each branch. These locations have been mapped to the corresponding counties by the authors.

KKK: change in the standardized (by black population) counts of Ku Klux Klan organizations (known as Klaverns) by county. Information on the location of Klan organizations has been obtained from two sources. For the year 1940, information on the location of each Klavern has been obtained from the Virginia Commonwealth University's project 'Mapping the Second $\mathrm{Ku}$ Klux Klan', which lists the exact location of each headquarter (in a latitude and longitude format), mapped to the counties by the authors. For the later period, the location by county has been obtained from 'The Present-Day Ku Klux Klan Movement: Report by the Committee on Un-American Activities. House of Representatives. Ninetieth Congress, First Session. 1967' (pp. 145-163), which reports information on active Klaverns between 1964-1966.

Presidential turnout: difference in the natural $\log$ of presidential turnout in 1964 and 1944, where presidential turnout is given by the votes cast in the 1964 and 1944 presidential elections divided by population of voting age. The data on votes cast in the presidential election are from Electoral Data for Counties in the United States: Presidential and Congressional Races, 18401972, ICPSR 8611. The data on population of voting age are from the Minnesota Population Center, National Historical Geographic Information System and from the U.S. Census. 
Cotton suitability: maximum potential cotton yield by county (e.g. cotton suitability index). Source:(Hornbeck and Naidu 2014)

Farm size: number of farms with 700 acres or more from United States Agriculture Data, 1840-2012, ICPSR 35206.

Number of blacks in the police force: the 1959 data have been digitized from Rudwick (1962) and the 1969 have been digitized from Southern Regional Council (1983).

Cotton yield: change in cotton yield computed as the difference in the natural log of cotton yields in 1964 and 1945, where the cotton yield is the number of cotton bales per acre of land devoted to the cultivation of cotton by county. Cotton bales and acres of land devoted to cultivation of cotton are from the United States Agriculture Data, 1840-2012, ICPSR 35206.

\section{Black elected officials.}

The share of black elected officials by type of office is the number of black elected officials in County Commissions, municipal council and judges as reported by the National Roster of Black Elected Officials, divided by the total number of elected officials for the corresponding offices at county level, as reported by the Census of Governments. Judges belong to courts whose jurisdiction does not exceed the boundaries of a county and include the following courts: city and municipal courts, traffic courts, family courts, juvenile courts, pro- bate courts, general sessions courts, and county courts. When the numerator is zero and the denominator is missing, the share is zero. The total number of black elected officials in each local office in the US South has been obtained by counting the black elected officials by office reported in the National Roster of Black Elected Officials in 1969, 1971, and for the period 1973-1980. These officials have been matched to the counties using the address provided by the Roster. The information on the total number of elected officials by type of office that is used to construct the share of black elected officials is only available from the Census of Governments in 1967 and 1977. Thus, for the period 1964-1972, 
the total number of elected officials by type of office are taken from the Census of Governments, Volume 1, Governmental Organization, Number 2, Popularly Elected Officials, 1967. For the period 1973-1982, elected officials by type of office are taken from the Census of Governments Volume 1, Governmental Organization, Number 2, Popularly Elected Officials, 1977.

Election rule of county governing bodies and police chiefs.

The information on the system of elections of members of county governing bodies and police chiefs comes from the Census of Governments, Elective Offices of State and Local Governments (1957) and from the National Roster of Black Elected Officials (NRBEO, 1980). We have used the summary information reported by the Census of Government (1957) and the NRBEO (1980) at state level to construct indicators for the system of elections of county governing bodies and police chiefs as detailed below.

Elected Police chiefs: indicator equal to one for counties in states where statutes and local charters allow for the election of police chiefs as reported by the Census of Government. The municipal police chief may also be called marshal in Arkansas, Florida, Mississippi, Texas. In Virginia, town police chiefs are called Sargeants. Based on this information, the indicator is equal to one for Arkansas, Florida, Louisiana, Texas and Virginia with the exception of independent cities where Sargeants do not act as police chiefs.

Single member districts (SMD): indicator equal to one for covered states where members of county governing bodies are elected by single member districts (Louisiana, Mississippi, and Virginia) and zero otherwise. 